by Jun Hee Lee ${ }^{l}$, Bong Chul Yoo ${ }^{2}$, Yun-Seok Yangl, Jung Hun Seo ${ }^{\text {* }}$, Jonguk Kim³, Jihye $\mathrm{Oh}^{3,4}$, and Ji-Hoon Kim

\title{
Indium and gallium enrichments in zinc orebodies in the Tae- baeksan region, Korea
}

\begin{abstract}
${ }^{1}$ Department of Energy Resources Engineering, Inha University, Incheon 22212, Republic of Korea; *Corresponding author, E-mail: seo@inha.ac.kr ${ }^{2}$ Development of Mineral Resources, Korea Institute of Geoscience and Mineral Resources, Daejeon 34132, Republic of Korea

${ }^{3}$ Deep-sea and Seabed Mineral Resources Research Center, Korea Institute of Ocean Science \& Technology, Busan 49111, Republic of Korea ${ }^{4}$ School of Earth and Environmental Sciences, Seoul National University, Seoul 08826, Republic of Korea

${ }^{5}$ Petroleum \& Marine Division, Korea Institute of Geoscience and Mineral Resources, Daejeon 34132, Republic of Korea
\end{abstract}

(Received: December 9, 2020; Revised accepted: February 12, 2021)

https://doi.org/10.18814/epiiugs/2021/021003

Indium (In) and gallium (Ga) have been regarded as the critical elements due to a large recent demand on high-tech applications but their relatively low crustal abundance. The presence of variable In and Ga contained in sphalerite has recently been reported from numerous magmatichydrothermal zinc orebodies in the Taebaeksan metallogenic region in Korea. Here we report chemical compositions of lithologies including granitoid intrusions and sedimentary sequences in the region and compare with associated sphalerites to investigate geological distributions and enrichment processes of In and Ga. While In in the lithologies are not generally detected by $L A-I C P-M S$, high concentrations up to 630 ppm in sphalerite suggest a significant In enrichment by magmatic-hydrothermal fluids. Major zinc mines show high In concentrations of an average $100 \mathrm{ppm}$ suggesting a potential of economic In orebodies in the region. Despite relatively moderate Ga contents up to 24 ppm in the hosting lithologies, Ga enrichment in sphalerite up to 66 ppm is rather limited compared to the In enrichment. The types and mineral assemblages of magmatichydrothermal sphalerite-bearing ores indicate that In is concentrated in relatively higher temperature, whereas Ga tends to be enriched in lower temperature. The enrichment processes of In and Ga in sphalerite might be strongly related to their complexations in the magmatic-hydrothermal fluids. High salinity in the fluid is favorable to form an In-chloride complex for mobilization and enrichment of In into sphalerite. Conversely, Ga-hydroxide complex might not be stable at relatively high temperature which could limit an economic enrichment of $G a$ in sphalerite in the region.

\section{Introduction}

Antimony, barite, beryllium, cobalt, fluorine, gallium, germanium, graphite, hafnium, indium, lithium, manganese, niobium, platinum-group elements, rare-earth elements, rhenium, selenium, tantalum, tellurium, tin, titanium, vanadium, and zirconium have been and assigned as the "critical element or mineral" due to their low crustal abundances and potential instabilities in the global supply chain (Schulz et al., 2017). In particular, indium (In) and gallium (Ga) are the key elements for the high-tech industrial applications such as LED flat panels, smartphones, electrical materials, photovoltaic, and batteries. Indium is mainly consumed for the indium tin oxide (ITO) as a transparent electrode, which is essential for a display industry. Chemical properties such as low melting points of In and Ga allow us to apply it as a liquid metal (eutectic Ga-In alloy; EGaIn) which is a promising material for a flexible electrode.

Indium is produced as a byproduct of $\mathrm{Zn}$ smelting mainly in China, Japan, and Korea, while the global In resources are mostly distributed in China (Lokanc et al., 2015; USGS, 2019). Gallium is mainly recovered as a byproduct of a processing of bauxite $\mathrm{Al}$ ore and lesser amounts are produced from a Zn smelting (Foley et al., 2017), and China accounts for most of the global Ga production (USGS, 2019). The average abundance of In and $\mathrm{Ga}$ in the upper crust are reported as $0.05 \mathrm{ppm}$ (Taylor and McLennan, 1995) and 17.5 ppm (Rudnick and Gao, 2003), respectively. Due to the low crustal abundance, In and Ga generally substitute for elements in minerals including sphalerite (e.g., $2 \mathrm{Zn}^{2+} \leftrightarrow$ $\mathrm{Cu}^{+}+\mathrm{In}^{3+}$; Johan, 1988) rather than presenting in the stoichiometry in minerals. Sphalerite $(\mathrm{ZnS})$ is the primary $\mathrm{Zn}$ ore containing a variety of minor and trace elements such as $\mathrm{Ag}, \mathrm{Cd}, \mathrm{Co}, \mathrm{Cu}, \mathrm{Fe}, \mathrm{Ge}, \mathrm{Mn}, \mathrm{Sb}$, and $\mathrm{Sn}$ in addition to In and $\mathrm{Ga}$ (Cook et al., 2009).

The Taebaeksan (TBS) region in South Korea is an important metallogenic region for $\mathrm{Zn}-\mathrm{Pb}-\mathrm{W}-\mathrm{Mo}-\mathrm{Fe}-\mathrm{Cu}(-\mathrm{Au}-\mathrm{Ag})$ and had been a significant $\mathrm{Zn}-\mathrm{Pb}$ producer accounting for $90 \%$ of the domestic production until 1994 (Yun and Einaudi, 1982; Lee et al., 2007; Choi et al., 2009). The $\mathrm{Zn}$ orebodies of skarn, carbonate replacement, and vein-breccia type in the TBS region are hosted in early Paleozoic carbonate sequence associated with the magmatic-hydrothermal activities of Late Cretaceous to early Paleogene (Yun and Silberman, 1979; Park et al., 1988). While chemical compositions and grades of the $\mathrm{Zn}$ ores from the TBS region have been studied (Yun and Einaudi, 1982; Choi et al., 
2009; Choi et al., 2010), no study has yet investigated critical elements in the ores and their economic potentials except for a preliminary study of Heo et al. (2008). Heo et al. (2008) reported In, Re, Ga, Ge, Se, Te, $\mathrm{Y}, \mathrm{Eu}$, and $\mathrm{Sm}$ contents in the ores from 34 metallic mines in Korea and they found relatively high In concentrations in the Gagok $\mathrm{Zn}-\mathrm{Pb}$ deposit (average of $53 \mathrm{ppm}$ ) in the TBS region.

In our previous study on sphalerite geochemistry (Lee et al., 2019), we have shown that the sphalerite found in the TBS region contains up to $630 \mathrm{ppm}$ of In and $66 \mathrm{ppm}$ of Ga. Considering an average In content (15-50 ppm; Roskill, 2010) in the ores from global In-producing mines, the economic potentials of In in the numerous $\mathrm{Zn}$ orebodies and prospects in South Korea are worthy of further research. Furthermore, critical elements have become important due to a large demand on high-tech applications, it is essential to understand geological dis- tributions of In and $\mathrm{Ga}$, and its enrichment processes.

In this paper, we investigated the $\mathrm{Zn}$ orebodies and prospects in the TBS region and provide the distributions of In and Ga based on the previously studied sphalerite compositions (Lee et al., 2019). We report chemical compositions of associating or hosting lithologies for $\mathrm{Zn}$ ores including granitoid intrusions and sedimentary sequences, and discuss enrichment processes of In and Ga into sphalerite.

\section{Geological Background}

\section{Taebaeksan Metallogenic Region}

The TBS basin, located in the northeastern part of the Korean Peninsula, consists of the Precambrian metamorphic basement of the Yeongnam
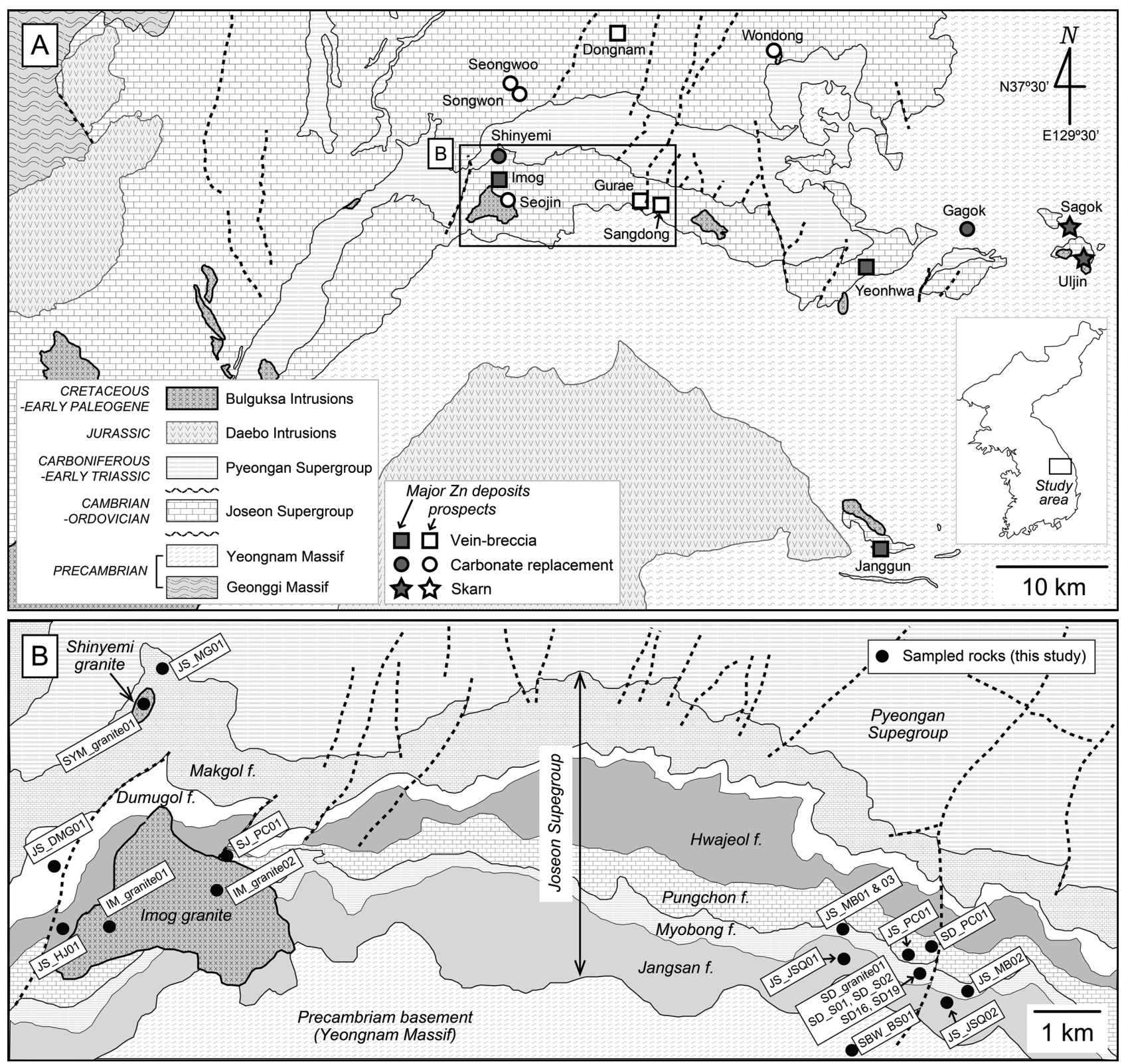

Figure 1. (A) Geological map of the Taebaeksan metallogenic region and location of the studied deposits with their predominant types of sphalerite-bearing ore. (B) Detailed geological map of the sampling sites showing sedimentary sequences in the TBS region. The map was modified after Lee et al. (2019). 
massif, sedimentary sequences composed of the early Paleozoic Joseon and late Paleozoic Pyeongan Supergroups, and granitoid intrusions of the Jurassic to early Paleogene (Fig. 1A). The Triassic Songrim orogeny and Jurassic Daebo event generated numerous folds and NNEtrending faults in the TBS region (Chough et al., 2000; Kim, 2019), which might provide the advantageous pathways for the ascending ore-forming fluids from Bulguksa granites of the late Cretaceous to early Paleogene age or the intrusion of the granite itself (Moon, 1991). The metallic deposits in the TBS region were formed by magmatichydrothermal activities mainly in 90-50 Ma constituting the TBS metallogenic region (Yun, 1986; Park et al., 1988; Park et al., 2013) which includes skarn, hydrothermal replacement, vein, and Carlin-like type deposits based on their proximity to the intruding magma sources (Choi et al., 2009). Most deposits and prospects are hosted in calcareous formations of the Joseon Supergroup which is generally composed of the Jangsan, Myobong, Pungchon, Hwajeol, Dongjeom, Dumugol, and Makgol Formations in ascending order. Major Zn deposits and prospects are localized to the southern part of the TBS region with higher ore grades and reserves, while the northern part is dominated by limestone and calcite marble deposits (Moon, 1991; Lee et al., 2019).

\section{Ore Deposits and Prospects of Zn in the TBS region}

\section{Yeonhwa and Gagok}

The Yeonhwa deposit had been the largest $\mathrm{Zn}-\mathrm{Pb}$ producer in Korea, producing concentrates of $0.82 \mathrm{Mt}$ of $\mathrm{Zn}$ and $0.25 \mathrm{Mt}$ of $\mathrm{Pb}$ from 1935 to 1986 (Je and Lee, 1987). The dikes of quartz porphyry intruded the area in the direction of NS and NW with the developments of pipeshaped skarn orebodies which are hosted in the Pungchon Formation and in minor calcareous beds of the Myobong Formation within the Joseon Supergroup (Yun and Einaudi, 1982). The K-Ar ages of sericite from ore-related quartz porphyry are reported as from 75.3 Ma to 73.6 Ma (Park et al., 1988; So et al., 1993). The Gagok deposit (also known as Yeonhwa II) was the second largest mine for $\mathrm{Zn}-\mathrm{Pb}$, producing concentrates of $0.62 \mathrm{Mt}$ of $\mathrm{Zn}$ and $0.03 \mathrm{Mt}$ of $\mathrm{Pb}$ from 1971 to 1987 (Yun and Einaudi, 1982; Choi et al., 2010). The Zn orebodies in Gagok show typical characteristics of skarn and carbonate replacement mineralization which are developed along the contact between the NS-trending intrusion of quartz monzonite porphyry and the Myobong-Pungchon Formations (Yun, 1979b). The mineralization age by $\mathrm{K}-\mathrm{Ar}$ dating of muscovite from a skarn ore are reported as $72.6 \mathrm{Ma}$ (Yun and Silberman, 1979).

\section{Uljin and Sagok}

The "Yeonhwa-Uljin mining district" is composed of $\mathrm{Zn}-\mathrm{Pb}$ deposits in the eastern TBS based on their similar geology and mineralization features, and the district accounted for $80 \%$ of domestic $\mathrm{Zn}-\mathrm{Pb}$ production until the 1980s (Yun, 1979a). The Uljin deposit, located in the easternmost part of the studied area, had produced $0.16 \mathrm{Mt}$ of $\mathrm{Zn}$ $\mathrm{Pb}$ concentrates from 1971 to 1986 (Choi et al., 2009). The Zn orebodies are partially distributed in the skarn zone within the Myobong-Pungchon Formations, which is associated with rhyodacite of 49.3 Ma dated by whole-rock K-Ar geochronology (Yun and Silberman, 1979). The Sagok deposit nearby the Uljin deposit was explored by the Young- pung Mining Company who operated the Yeonhwa-Uljin mining district, but there are no reported records of the $\mathrm{Zn}-\mathrm{Pb}$ productions. Skarn $\mathrm{Zn}-\mathrm{Pb}$ mineralization hosted in the Pungchon Formation is dominant in the area.

\section{Janggun}

The Janggun deposit in the southern margin of the TBS region is a polymetallic deposit of $\mathrm{Zn}-\mathrm{Pb}-\mathrm{Ag}, \mathrm{Mn}, \mathrm{V}$, and Fe (Lee et al., 2007). The deposit had started to exploit Mn on the surface since 1940s, but produced $0.25 \mathrm{Mt}$ of $\mathrm{Zn}$ and $0.14 \mathrm{Mt}$ of $\mathrm{Pb}$ concentrates during the period 1977-2001 as the $\mathrm{Zn}-\mathrm{Pb}$ orebodies were discovered in underground (Lee et al., 1990; Choi et al., 2009). Lens- and pipe-shaped orebodies are hosted in the Janggun limestone Formation of the Joseon Supergroup which was structurally controlled by the Jurassic Chunyang granite (148.5 Ma). The K-Ar ages of sericite from $\mathrm{Zn}-\mathrm{Pb}$ ore yielded 70.0-73.6 Ma (Lee et al., 1996).

\section{Shinyemi and Imog}

The Shinyemi deposit is hosted in the Makgol Formation of the Joseon Supergroup associated with the Cretaceous granitoid intrusions (Shinyemi granitoid). The skarn and carbonate replacement type orebodies in Shinyemi are divided into Fe-Mo-Zn rich western orebody and $\mathrm{Zn}-\mathrm{Cu}-\mathrm{Pb}$ rich eastern orebody (Sato et al., 1981; Seo et al., 2020). The mine had produced $56 \mathrm{kt}$ of $\mathrm{Zn}$ and $90 \mathrm{t}$ of $\mathrm{Pb}$ concentrates from the eastern and upper western orebodies from 1970 to 1982 (Choi et al., 2009), but has currently been exploited for magnetite ores from the lower western orebody. The Shinyemi granitoid intruded to the NNE direction at 74.7-77.2 Ma dated by K-Ar geochronology of biotite and K-feldspar (Yang, 1991), which are comparable to the mineralization age of 75.3-77.7 Ma by phlogopite K-Ar dating (Sato et al., 1981; Park et al., 1988). The Imog deposit close to Shinyemi is composed of skarn and hydrothermal vein orebodies mainly hosted in the Dumugol Formation of the Joseon Supergroup. The Imog granite, which is suggested to be a causative intrusion for the deposit, yielded K-Ar ages of 92.0-96.7 Ma on biotite (Hong, 1986; Yun, 1986). The W skarn mineralization is developed near the Imog granite while the $\mathrm{Zn}-\mathrm{Pb}$ hydrothermal vein mineralization postdates in the distal part from the skarn along the NE-trending faults of the area (Im et al., 2020; Seo et al., 2020). Im et al. (2016) reported K-Ar ages of 83.6-97.5 Ma for sericite from the $\mathrm{Zn}-\mathrm{Pb}$ ores.

\section{Dongnam}

The Dongnam deposit is a polymetallic deposit for Fe, Mo, $\mathrm{Zn}-\mathrm{Pb}$, $\mathrm{Ag}$, and $\mathrm{Mn}$. The magnetite ores were a main commodity of the mine which had been exploited until the 1960s. The Myobong and the Pungchon Formations in the area were intruded by Cretaceous granitoids of porphyritic granites, diorite, and quartz porphyry (Chang et al., 1995). The irregular pocket-shaped skarn Fe orebodies are dominated in the deposit with minor amounts of sphalerite and galena, which are developed in the contact between the Pungchon Formation and the intrusion of diorite (Chang et al., 1995; Lee et al., 2007). The phlogopite coexisting with the vuggy magnetite ore yielded a K-Ar age of 79.6 Ma (Park et al., 1988). 


\section{Wondong}

The Makgol Formation in the Wondong area hosts various orebodies of $\mathrm{Fe}, \mathrm{Zn}-\mathrm{Pb}$, and W-Mo associated with the Cretaceous intrusions of rhyolite and quartz porphyry. The carbonate replacement type $\mathrm{Zn}-\mathrm{Pb}$ orebody occurs as stratiform and pipe-shape which is developed in the northwest of the early skarn Fe orebody (Hwang and Lee, 1998). Recent cross-hole survey confirmed the hidden $\mathrm{Zn}-\mathrm{Pb}$ orebody in depth with an average grade of $5.50 \%$ (Lee, 2011). The quartz porphyry intrusion widely distributed in the area is cut by sheeted sub-vertical quartz veins with sericitic to argillic alteration. While the $\mathrm{U}-\mathrm{Pb}$ age of zircon from quartz porphyry is $79.4 \mathrm{Ma}$, the $\mathrm{K}$-Ar ages of phlogopite coexisting with magnetite ore are reported as 49.2-52 Ma (Park et al., 1988; Park et al., 2013).

\section{Sangdong and Gurae}

The Sangdong W-Mo (-Bi) deposit had been a world class W producer. The strata-bound scheelite-molybdenite orebodies in Sangdong are mainly hosted in the carbonate-rich layers which are intercalated within the Myobong Formation (e.g., M1 layer). The Sangdong deposit consists of early skarn and subsequent magmatic-hydrothermal veining stages which comprise the zonation of garnet-wollastonite skarn, pyroxene skarn, amphibole alteration, and mica alteration from periphery to center of the deposit (Fig. 2) (John, 1963; Moon, 1989; Seo et al., 2017). Minor amounts of sphalerite occur in the later-stage veins associated with muscovite alteration. The muscovite Ar-Ar age of 86.6-87.2 Ma (Seo et al., 2017) is similar to the K-Ar age of the Sangdong granite beneath the Jangsan Formation (87.5 Ma; Kim, 1986), which might be a causative intrusion for the mineralization. In the Gurae prospect near the Sangdong deposit, minor $\mathrm{Zn}-\mathrm{Pb}-\mathrm{Fe}-\mathrm{Cu}$ (-W-Mo) orebody was explored by the geochemical survey (Yoo et al., 2016). Sphalerite-rich quartz veins are developed along the fault hosted in the intercalated carbonate-rich layer within the Myobong Formation.

\section{Seongwoo, Songwon, and Seojin}

The Seongwoo, Songwon, and Seojin are calcite marble deposits exploiting the upper part of the Pungchon Formation. Thrust faults in the NE direction are developed in the areas of Seongwoo and Songwon (Yoo et al., 2016). While no outcrops of intrusion exist in the area, small-scale carbonate replacement $\mathrm{Zn}-\mathrm{Pb}-\mathrm{Fe}-\mathrm{Cu}$ orebodies are associated with calcite marble along generally through the faults. The Seojin deposit show a close spatial relationship with the Imog $\mathrm{Zn}$-Pb deposit and the Imog granite. Minor metallic mineralization of pyrrhotite and pyroxene skarn are developed in the contact between the upper Pungchon Formation and the Imog granite. Sphalerite occurs in quartz-sulfide vein which crosscuts the pyroxene skarn.

\section{Petrography of Samples}

We collected total 20 samples including sedimentary rock, igneous rock, and metamorphic rock near the Shinyemi, Imog, and Sangdong deposits, which are the representative hosting or associating lithologies of the $\mathrm{Zn}$ ores in the southern part of the TBS region (Fig. 1B). Igneous rocks were sampled from the outcrops (Imog granite) and drill cores (Shinyemi and Sangdong granites) which are the representative Cretaceous intrusions related to the mineralization in the southern TBS region. Some rock samples were obtained from skarn and hydrothermal alteration zones in the Sangdong deposit (Fig. 2) (Seo et al., 2020) to investigate an enrichment process of In and Ga during the magmatic-hydrothermal process. Summarized descriptive information of the collected samples are reported in Table S1.

\section{Sedimentary Rocks in the Joseon Supergroup}

The samples from the Jangsan Formation, which is the lowermost sequence of the Joseon Supergroup, mostly consist of quartzite with minor disseminated pyrite and fine-grained sericite (JS_JSQ01 and JS_JSQ02, respectively). The rocks from the Myobong Formation are composed of a laminated dark gray slate (JS_MB01) and a massive slate with intercalated mudstone (JS_MB02). Intercalated limestone sample (JS_MB03) from M1 layer in the Myobong Formation contains partly recrystallized calcite and is later cut by quartz veinlets.

\section{Sangdong W-Mo deposit (main orebody)}

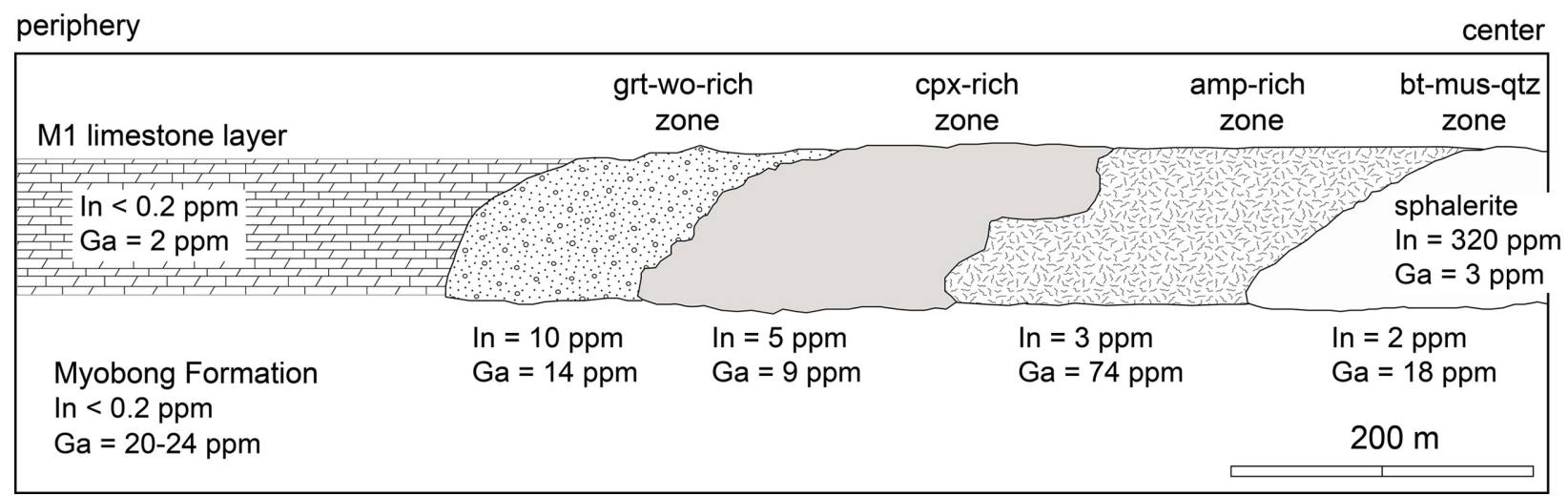

Figure 2. Schematic cross section of the zonational patterns in the Sangdong W-Mo deposit and associated In and Ga concentrations (modified after Seo et al., 2020). Sphalerites occur in the late quartz vein in bt-mus-qtz zone. The sphalerite in the Sangdong deposit is significantly enriched in In, whereas depleted in Ga even less than associating host rocks and skarns. Abbreviations: grt = garnet, wo = wollastonite, cpx = clinopyroxene, amp = amphibole, $b t=$ biotite, mus $=$ muscovite. 
Three limestone samples were collected from the lower and upper parts from the Pungchon Formation. The lower part of Pungchon (JS_PC01) consists of a massive dark gray limestone which partly contains oolitic texture. The upper part samples are characterized by a recrystallized white calcite of sugary texture (SJ_PC01) or a coarsegrained calcite up to a few centimeters (SD_PC01). The rocks in the Hwajeol and the Dumugol Formations are mainly composed of gray limestone. While the sample from Hwajeol contains fine-grained crystallized calcite in a massive limestone (JS_HJ01), a laminated limestone with lenticular calcite is dominant in the Dumugol sample (JS_DMG01). The Makgol Formation, which is widely distributed in the Shinyemi deposit, consists of a dolomitic limestone of light gray color (JS_MG01).

\section{Cretaceous Intrusions}

The sample of the Sangdong granite (SD granite01) is mediumgrained feldspar-rich granite consisting of K-feldspar, muscovite, quartz, plagioclase, and minor chalcopyrite and molybdenite with partial sericitic to chloritic alterations. The granites from the Shinyemi and the Imog deposits (SYM_grnite01 and IM_granite01, respectively) are pinkish feldspar biotite granite which have a similar mineralogy consisting of $\mathrm{K}$-feldspar, biotite, plagioclase, and quartz, but different textures are observed. While the SYM_granite01 sample is dominated by finegrained K-feldspar and biotite, the IM_granite01 sample shows a seriate texture of coarse-grained K-feldspar and fine- to medium-grained biotite and plagioclase.

\section{Metamorphic and Altered Rocks}

The Precambrian basement sample (SBW_BS01) was collected from the Sunbawi area near the Sangdong deposit. The sample is characterized by a muscovite-rich metasediment of siltstone to sandstone origin.

The samples from the outer part of the Sangdong deposit show anhydrous skarn mineral assemblages (Fig. 2). Euhedral garnet (andradite to grossular) and interstitial wollastonite are dominant in the SD_S01 sample, and clinopyroxene and minor disseminated scheelite are observed in the SD_S02 sample. SD19 and SD16 were sampled from the inner part, which are altered by quartz veins postdating the early skarns (Fig. 2). The SD19 sample is dominated by an amphibole-magnetite alteration, and the SD16 sample shows a biotite-muscovite alteration.

\section{Sphalerite-bearing Ores}

Detailed petrography of sphalerite-bearing ores including descriptions, paragenetic sequence, and mineralogical features were reported in Lee et al. (2019). We classified the Zn-bearing ore samples into the types of 1) skarn, 2) carbonate replacement, and 3) vein-breccia based on their textures and mineralogies associating the sphalerite mineralization. While oxide minerals (e.g., magnetite and scheelite) and molybdenite are dominant in relatively high-T skarn and vein-breccia type ores, base-metal sulfides including sphalerite, arsenopyrite, galena, and chalcopyrite are common in relatively low-T carbonate replacement type ores.

\section{Analytical Methods}

Powdering of the collected rock samples was conducted at Korea Polar Research Institute (KOPRI) after petrographic analysis. Twenty fresh rock samples were ground in an agate ball mill. The whole rock powders were used for Rock-Eval Pyrolysis and for making homogeneous glass beads prior to XRF and LA-ICP-MS analysis. The details of each analytical method are as follows.

\section{Rock-Eval Pyrolysis}

Total organic carbon (TOC) and mineral carbon (MinC) contents in bulk rocks were measured by a Rock-Eval pyrolysis using Vinci Technologies Rock-Eval 6 (Lafargue et al., 1998) housed at Korea Institute of Geoscience and Mineral Resources (KIGAM). IFP 16000 was used as a standard, and the analytical reproducibility for TOC and MinC was better than $2 \%$.

\section{Bulk XRF and LA-ICP-MS analysis of the Fused Glasses}

XRF analysis of the collected samples was conducted at KOPRI. The whole rock powders were initially weighed to determine loss-onignition (LOI) before heating at a furnace of $1000^{\circ} \mathrm{C}$ for at least 20 minutes. Dried powder of $0.6 \mathrm{~g}$ and flux of $6 \mathrm{~g}$ (lithium tetraborate; $\mathrm{Li}_{2} \mathrm{~B}_{4} \mathrm{O}_{7}$ ) were mixed into a platinum crucible and the mixture was fused in Katanax K2 Prime to make a glass bead. The glass beads of in-house reference materials (BCR-2, STM-2, JG-3) and a blank (only a flux) were made under the same condition to calibrate specific trace elements which might be contained in a flux or in a crucible. Produced homogenous glass beads were loaded in X-ray fluorescence spectrometer (Malvern Panalytical Axios mAX) to acquire major elements including $\mathrm{Si}, \mathrm{Ti}, \mathrm{Al}, \mathrm{Fe}, \mathrm{Mn}, \mathrm{Mg}, \mathrm{Ca}, \mathrm{Na}, \mathrm{K}$, and $\mathrm{P}$ as oxides.

Subsequently after the XRF analysis on the glass beads, trace element concentrations were determined by Laser Ablation (LA) ICP-MS at Korea Institute of Ocean Science \& Technology (KIOST). The LAICP-MS consists of a $193 \mathrm{~nm}$ ArF Excimer laser connected to a quadrupole mass spectrometer (Agilent 7700). The ablation was conducted using a $150 \mu \mathrm{m}$ beam diameter with a repetition rate of $5 \mathrm{~Hz}$. The glass beads were loaded with NIST610 glass as an external standard. Quantification of trace elements and data reduction were performed using a SILLS software (Guillong et al., 2008). While $\mathrm{SiO}_{2}$ content was mostly used as an internal standard, $\mathrm{CaO}$ content was used for carbonate rocks which was obtained from XRF analysis. Lithium and $\mathrm{B}$, which are the major elements in the flux material for glass beads, were excluded from the consideration of trace elements. Chromium, $\mathrm{Ni}, \mathrm{Zn}$, and Au were also excluded which are contained in a considerable amount in the blank bead.

\section{Results}

The complete dataset of chemical compositions of the studied samples is reported in Table S2. Trace element concentrations obtained by LA-ICP-MS are presented in an average of 3 ablated spots of each samples. 


\section{Rock-Eval Pyrolysis}

TOC contents in all the studied igneous rocks are below detection limits. Sedimentary and metamorphic rocks have low TOC contents less than $0.2 \mathrm{wt} \%$, and the highest TOC content of $0.15 \mathrm{wt} \%$ is found in the M1 layer of the Sangdong deposit. Skarn (SD_SD01, SD_S02) and altered rocks (SD16, SD19) also have low TOC contents which range from 0.02 to $0.07 \mathrm{wt} \%$. MinC contents were mostly detected in carbonate-rich formations of the Joseon Supergroup ranging approximately $10 \mathrm{wt} \%$. Any relationship between organic carbon contents according to stratigraphy in the TBS region is not observed.

\section{Major and Trace Elements}

$\mathrm{SiO}_{2}$ and $\mathrm{Na}_{2} \mathrm{O}+\mathrm{K}_{2} \mathrm{O}$ contents in igneous rocks range from 66.9 to $75.4 \mathrm{wt} \%$ and from 7.1 to $8.2 \mathrm{wt} \%$, respectively. The Shinyemi granite has the highest silica and alkali contents followed by the Sangdong and the Imog granite. $\mathrm{Al}_{2} \mathrm{O}_{3}$ contents in the igneous rocks are 13.0$14.3 \mathrm{wt} \%$ which indicates that all the studied igneous rocks are peraluminous granites. Most of carbonate-rich formations of the Joseon Supergroup has LOI of about $40 \mathrm{wt} \%$, and the $\mathrm{CaO}$ content is the highest in the Pungchon Formation (48.4-52.6 wt\%). The Myobong Formation (JS_MB01, JS_MB02) contains high $\mathrm{Al}_{2} \mathrm{O}_{3}$ (16.7-19.4 wt \%) and $\mathrm{Fe}_{2} \mathrm{O}_{3}(7.7-12.1 \mathrm{wt} \%)$ contents compared to other sedimentary sequences.

Indium was generally below the detection limits (about $0.2 \mathrm{ppm}$ ) by LA-ICP-MS analysis on the fused glasses, whereas Ga was detected in most of the studied rock samples. Indium concentrations were low in the Imog granite (1.2 ppm) and in the Pungchon and Makgol Formations (0.2 ppm). Skarn samples from the Sangdong W-Mo deposit contain relatively high In concentrations ranging from 4.5 to $10.3 \mathrm{ppm}$ compared to the samples from alteration zone ranging from 1.5 to $2.5 \mathrm{ppm}$ (Fig. 2). Gallium was found to be one to ten ppm in the studied rocks. Gallium concentrations in sedimentary rocks in the Joseon Supergroup are highly variable. The highest Ga concentrations up to $24.1 \mathrm{ppm}$ were found in the Myobong Formation while the rocks from the Pungchon Formation were below detection limits (about $0.7 \mathrm{ppm}$ ). The granites in the region show a comparable range of Ga concentrations (13.4-17.1 ppm) while showing the highest in the Sangdong granite.

Vanadium concentrations are relatively high in the Imog granite (43-46 ppm) and in slate-rich layer of the Myobong Formation (122$380 \mathrm{ppm}$ ) among the analyzed rock samples. Cobalt was found to be

Table 1. Stratigraphic column and In and Ga concentrations in lithology in the Taebaeksan metallogenic region (modified after Moon et al., 1989; Seo et al., 2020)

\begin{tabular}{|c|c|c|c|c|}
\hline $\begin{array}{l}\text { Stratigraphy \& } \\
\text { ages of lithology }\end{array}$ & $\begin{array}{l}\text { Intrusion and For- } \\
\text { mation (thickness } \\
\text { in meter) }\end{array}$ & General lithology & $\begin{array}{l}\text { Bulk In and Ga concentra- } \\
\text { tions in intrusions and host } \\
\text { rocks (this sutdy; ppm) }\end{array}$ & $\begin{array}{l}\text { In and Ga concentrations } \\
\text { in sphalerite } \\
\text { (Lee et al., 2019; ppm) }\end{array}$ \\
\hline late Cretaceous intrusion & Imog granite & $\begin{array}{l}\text { K-feldspar \& biotite rich seriate } \\
\text { holocrystalline granite }\end{array}$ & $\mathrm{In}=1, \mathrm{Ga}=13-14$ & \\
\hline late Cretaceous intrusion & Shinyemi granite & $\begin{array}{l}\text { K-feldspar \& biotite rich fine-grained } \\
\text { granite or quartz porphyry }\end{array}$ & $\mathrm{In}=\mathrm{bdl}, \mathrm{Ga}=15$ & \\
\hline late Cretaceous intrusion & Sangdong granite & $\begin{array}{l}\text { K-feldspar \& muscovite rich } \\
\text { equigranular granite }\end{array}$ & $\mathrm{In}=\mathrm{bdl}, \mathrm{Ga}=17$ & \\
\hline $\begin{array}{c}\text { Pyeongan Supergroup } \\
\text { (Carboniferous-early } \\
\text { Triassic) }\end{array}$ & & $\begin{array}{l}\text { Various lithologies incuding shale, } \\
\text { sandstone, conglomerate and limestone }\end{array}$ & & \\
\hline \multirow{9}{*}{$\begin{array}{l}\text { Joseon Supergroup } \\
\text { (Cambrian-Ordovician) }\end{array}$} & Makgol (250-300) & $\begin{array}{l}\text { Dark gray limestone and } \\
\text { dolomitic limestone }\end{array}$ & $\mathrm{In}=0.2, \mathrm{Ga}=1$ & $\begin{array}{l}\text { Shinyemi }(\mathrm{In}=2-630, \mathrm{Ga}=1-18) \text {, } \\
\text { Wondong }(\mathrm{In}=7-40, \mathrm{Ga}=1-2)\end{array}$ \\
\hline & Dumugol (200-250) & $\begin{array}{l}\text { Interlayered carbonate-shale, } \\
\text { vermicular limestone and sandy shale }\end{array}$ & $\mathrm{In}=\mathrm{bdl}, \mathrm{Ga}=3$ & $\operatorname{Imog}(\operatorname{In}=0.1-0.4, \mathrm{Ga}=24-61)$ \\
\hline & Dongjeom (20-30) & Dark gray quartzite & & \\
\hline & Hwajeol (100-150) & $\begin{array}{c}\text { Interlayered carbonate-shale, } \\
\text { vermicular limestone and sandy shale }\end{array}$ & $\mathrm{In}=\mathrm{bdl}, \mathrm{Ga}=5$ & \\
\hline & \multirow{3}{*}{$\begin{array}{l}\text { Pungchon } \\
(350-400)\end{array}$} & $\begin{array}{l}\text { Upper part: milky-white } \\
\text { limestone or marble }\end{array}$ & $\begin{array}{l}\text { In }=0.2, \mathrm{Ga}=\mathrm{bdl} \\
(\text { calcite marble })\end{array}$ & $\begin{array}{l}\text { Seongwoo }(\mathrm{In}=0.1-11, \mathrm{Ga}=2-66), \\
\text { Songwon }(\operatorname{In}=36-38, \mathrm{Ga}=7), \\
\text { Seojin }(\operatorname{In}=170-240, \mathrm{Ga}=1-2)\end{array}$ \\
\hline & & $\begin{array}{l}\text { Middle part: light gray } \\
\text { dolomitic limestone }\end{array}$ & & \\
\hline & & $\begin{array}{l}\text { Lower part: light gray to dark } \\
\text { gray limestone }\end{array}$ & $\mathrm{In}=\mathrm{bdl}, \mathrm{Ga}=\mathrm{bdl}$ & $\begin{array}{l}\text { Yeonhwa }(\mathrm{In}=58-130, \mathrm{Ga}=4-28), \\
\text { Gagok }(\mathrm{In}=9-49, \mathrm{Ga}=0.7-6) \\
\text { Uljin }(\mathrm{In}=79-83, \mathrm{Ga}=2-4), \\
\text { Sagok }(\operatorname{In}=12-13, \mathrm{Ga}=1), \\
\text { Dongnam }(\operatorname{In}=1-32, \mathrm{Ga}=1-2)\end{array}$ \\
\hline & Myobong (80-150) & $\begin{array}{l}\text { Clay-rich slaty shale with thin } \\
\text { carbonate-rich layers or lenses }\end{array}$ & $\begin{array}{c}\mathrm{In}=\mathrm{bdl}, \mathrm{Ga}=20-24 \text { (slate) } \\
\mathrm{In}=\mathrm{bdl}, \mathrm{Ga}=2(\mathrm{M} 1 \text { carbon- } \\
\text { ate layer }), \mathrm{In}=2-10, \mathrm{Ga}= \\
9-74(\text { skarn and alteration })\end{array}$ & $\begin{array}{c}\text { Sangdong }(\mathrm{In}=310-330 \\
\mathrm{Ga}=3-4), \mathrm{Gurae}(\mathrm{In}=7-8 \\
\mathrm{Ga}=1)\end{array}$ \\
\hline & Jangsan (150-200) & Light to dark gray quartzite & $\mathrm{In}=\mathrm{bdl}, \mathrm{Ga}=3-4$ & \\
\hline $\begin{array}{l}\text { Metamorphic basement } \\
\text { (Precambrian) }\end{array}$ & & $\begin{array}{c}\text { Mica-rich metasedimentary rock } \\
\text { (dominantly schist) and granitic gneiss }\end{array}$ & $\mathrm{In}=\mathrm{bdl}, \mathrm{Ga}=9$ & \\
\hline
\end{tabular}


high in the Makgol Formation up to $100 \mathrm{ppm}$. Germanium was not detected in all rocks except for the skarn rocks in the Sangdong deposit (26-61 ppm). Molybdenum appeared in trace amounts in the Sangdong granite (1.7 ppm) and the lower part of the Pungchon Formation (0.6 ppm). Tungsten was detected in all the lithologies except the Hwajeol Formation, and the highest concentration was found in the Sangdong granite (44 ppm). Tungsten concentrations are generally around $30 \mathrm{ppm}$ in the sedimentary sequences of the Joseon Supergroup.

Indium and Ga concentrations in all studied lithologies are reported in Table 1, and we compare them with the concentrations in sphalerites associated or hosted in the lithologies. The sphalerites were inclusion-free without the texture of "chalcopyrite disease" or micro-inclusions (Lee et al., 2019). Although the rocks contain relatively low concentrations of In and $\mathrm{Ga}$, In and $\mathrm{Ga}$ concentrations in sphalerites show varying ranges from 0.1 to $630 \mathrm{ppm}$ and from 0.7 to $66 \mathrm{ppm}$, respectively. The average In concentrations in sphalerites were found to be high in the order of the ore types of vein-breccia (86 ppm), skarn (56 $\mathrm{ppm}$ ), and carbonate replacement (9 ppm). Gallium was the highest in the carbonate replacement (20 ppm) followed by the vein-breccia (13 ppm) and the skarn (5 ppm) types (Lee et al., 2019).

\section{Discussion}

\section{Distributions of In and Ga in the TBS sphalerites}

Histograms of In and Ga concentrations in sphalerites from the various deposits in the TBS region are respectively illustrated in Figs. 3 and 4 (modified after Lee et al., 2019). High In concentrations up to
$630 \mathrm{ppm}$ are in the sphalerites in the Yeonhwa, Gagok, Uljin, and Shinyemi deposits where $\mathrm{Zn}$ ores had been produced as a main commodity. The average In concentration of these deposits is $100 \mathrm{ppm}$, which is higher than those of global In-producing mines (15-50 ppm; Roskill, 2010). Indium in the TBS region, therefore, can potentially be an economic in the near future, if the $\mathrm{Zn}$ reserves in the aforementioned deposits are secured.

Indium concentrations are variable within the same deposit depending on its ore types (Fig. 3 and Table 1). In the Shinyemi deposit, skarn and vein-breccia type ores contain respective averages of $570 \mathrm{ppm}$ and $57 \mathrm{ppm}$, whereas carbonate replacement ores have an average of $2.5 \mathrm{ppm}$. The features are thus indicating that we require a further detailed chemical analysis for the specific ore type of sphalerites, which is mainly exploited in the mines. Indium was also enriched in the Sangdong W-Mo deposit (average of $320 \mathrm{ppm}$ ) and Seojin calcite marble deposit (average of $200 \mathrm{ppm}$ ), but the economic $\mathrm{Zn}$ orebodies are not discovered yet in the areas.

About $90 \%$ of global Ga has currently been produced by processing bauxite ores (Rongguo et al., 2016) which are reported to contain Ga about an average of 57 ppm (Schulte and Foley, 2014). The rest of $\mathrm{Ga}$ is produced through smelting of $\mathrm{Zn}$ ores from sedimenthosted deposits including MVT (Mississippi Valley-type; average of $58 \mathrm{ppm}$ ) and SedEx (Sedimentary Exhalative; average of $26 \mathrm{ppm}$ ) (Schulte and Foley, 2014; Foley et al., 2017). Among the major Zn deposits in this study, recognizable Ga concentrations are only found in the Imog and Janggun deposits (Fig. 4) with an average of about $40 \mathrm{ppm}$ indicating an economic potential for Ga in the TBS region is limited.

In concentration in sphalerite from global In mine

(15-50 ppm; Roskill, 2010)
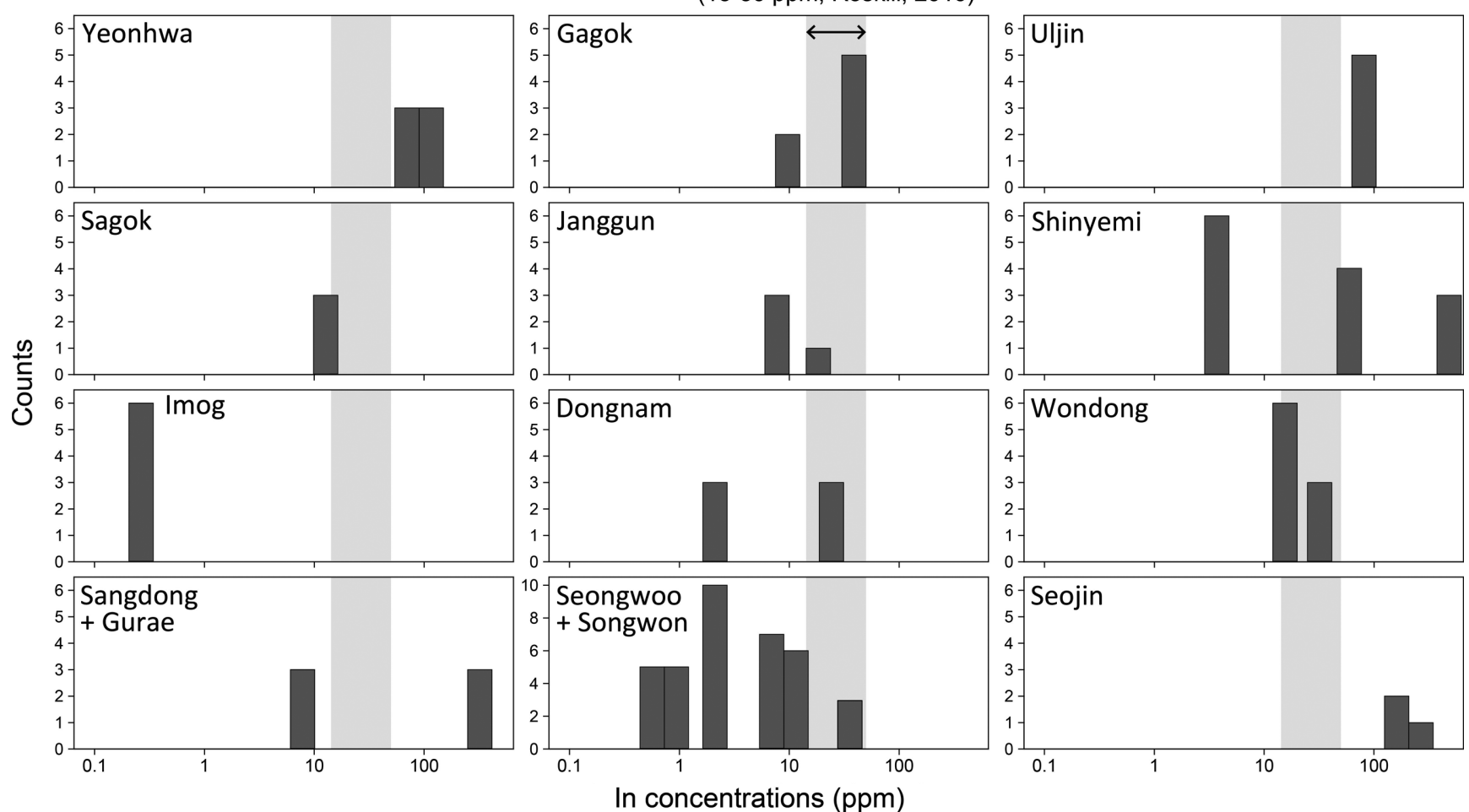

In concentrations (ppm)

Figure 3. Histograms showing In concentrations in inclusion-free sphalerites analyzed from studied deposits. Data are from Lee et al. (2019). 
(average 57 ppm; Schulte and Foley, 2014)
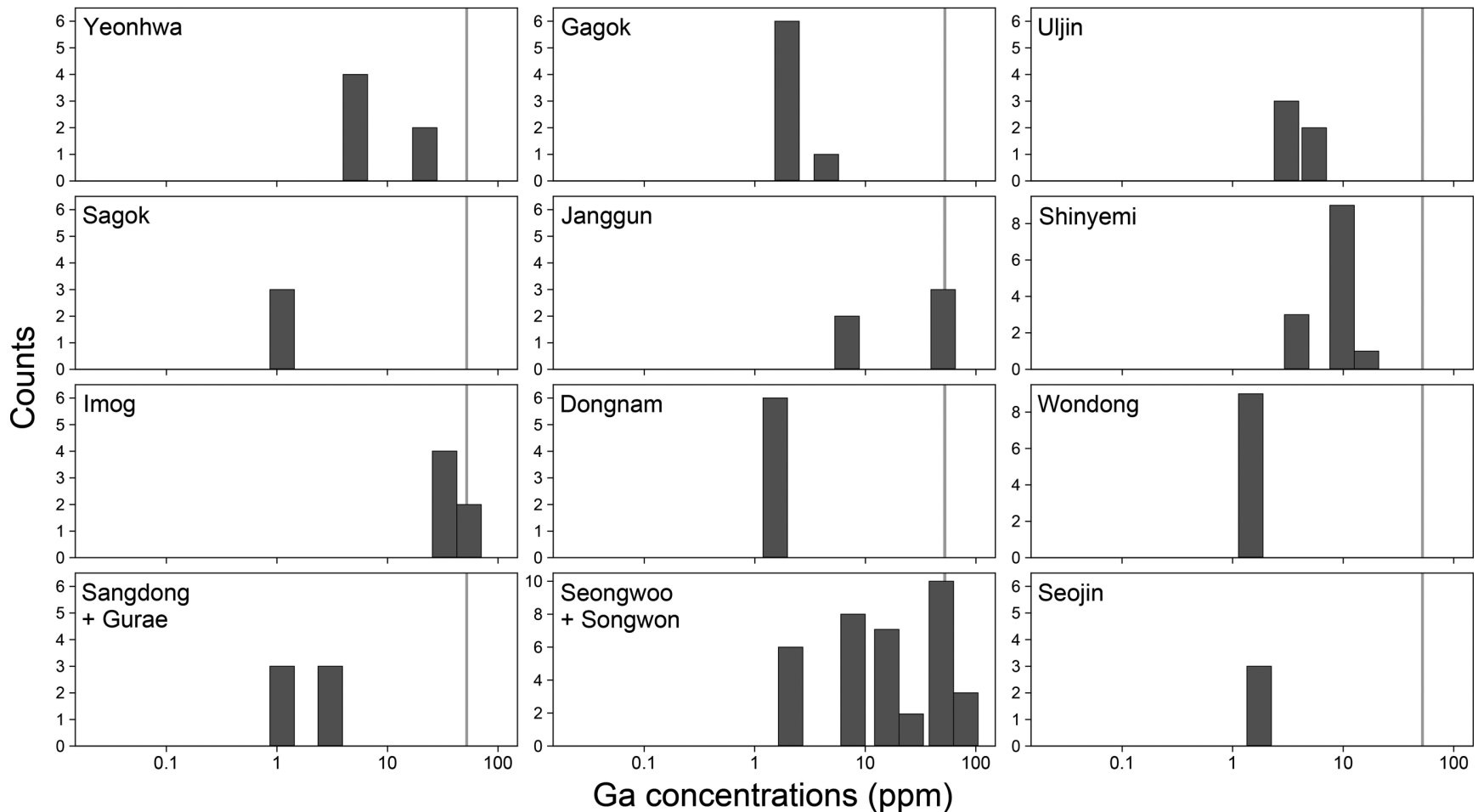

Figure 4. Histograms showing Ga concentrations in inclusion-free sphalerites analyzed from studied deposits. Data are from Lee et al. (2019).

\section{Concentrations of In and Ga in Intrusions and Sedimen- tary Sequences}

The In contents in granite and carbonate rock are generally low ranging from ten to $500 \mathrm{ppb}$ (Schwarz-Schampera and Herzig, 2002 and references therein). Indium concentrations in the Cretaceous intrusions and the carbonate rocks in the southern TBS region associating the $\mathrm{Zn}$ deposits and the $\mathrm{Zn}$ prospects are found to be below detection limits (generally less than $0.2 \mathrm{ppm}$; Table S2), while the In concentrations in sphalerites are considerably higher compared to the associating lithologies (Table 1). Lead isotope ratios in the TBS sphalerite suggest that the $\mathrm{Zn}$ ores in the TBS region are strongly associated with a hydrothermal activity caused by the Cretaceous granitoid intrusions (Lee et al., 2019). The presence and enrichment of In in the sphalerite indicate apparent hydrothermal affinities during the In mineralization (Audétat and Zhang, 2019) and suggest that In is significantly concentrated by Cretaceous magmatic-hydrothermal processes in the TBS region.

Indium is reported to be relatively incompatible during granite fractionation (Simmons et al., 2017). Indium-rich sphalerites commonly occur in magmatic-hydrothermal Sn-polymetallic deposits distributed in Japan, China, and Bolivia (Ishihara et al., 2011), and Murakami and Ishihara (2013) suggested that an oxidized magmatic source is essential for the In enrichment. The Cretaceous intrusions in the TBS region are commonly fractionated I-type and magnetite-series granitoids (Choi et al., 2019; Seo et al., 2020), which might be favorable to the In enrichment in sphalerite.

Gallium contents in the rocks in the continental crust are much higher than In, reported to be 16-35 ppm in granite, average of $4 \mathrm{ppm}$ in carbonate rocks, and average of 19 ppm in shale (Burton and Culkin,
1978; Mielke, 1979), and the those reported Ga contents are comparable to the rocks in the TBS region (Table 1). Aluminum in aluminosilicate minerals can be easily substituted by Ga due to their similar geochemical affinities (Burton et al., 1959). Except for in the skarn and altered rocks in the Sangdong W-Mo deposit, Ga concentrations showed a strong positive correlation with $\mathrm{Al}(\mathrm{r}=0.98$; inset of Fig. 5). While $\mathrm{Al} / \mathrm{Ga}$ ratios in the associating igneous and sedimentary rocks tend to remain constant about 4000 , the hydrothermally affected lithologies such as skarn and altered rocks (e.g., Sangdong W-Mo deposit) show lower and highly variable Al/Ga ratios (from 220 to 3200; Fig. 5). This trend of $\mathrm{Al} / \mathrm{Ga}$ ratios suggests that $\mathrm{Ga}$ can also be remobilized and enriched by magmatic-hydrothermal activities.

Despite an incompatible affinity of Ga during fractionation of magma (Breiter et al., 2013; Simmons et al., 2017), Ga in sphalerite is significantly depleted (2.9 ppm) compared to In (320 ppm) in the Sangdong W-Mo deposit (Fig. 2) where an extensive batholith-scale fractionation of magma caused an enrichment of incompatible element such as W and Mo (Seo et al., 2020). In general, Ga concentrations in sphalerites are generally low compared to In in the TBS region (Table 1). Here we further discuss this distinctive enrichment processes of In and $\mathrm{Ga}$ into sphalerite in the following texts.

\section{Mineralization Temperatures and Associating Mineral Assemblages of Sphalerite}

In the TBS region, sphalerites in the carbonate replacement type or paragenetically late-stage ores generally contain low In (up to $40 \mathrm{ppm}$ ) and high $\mathrm{Ga}$ (up to $66 \mathrm{ppm}$ ) (Lee et al., 2019). Indium tends to be enriched in sphalerite from the relatively high temperature deposits associated 


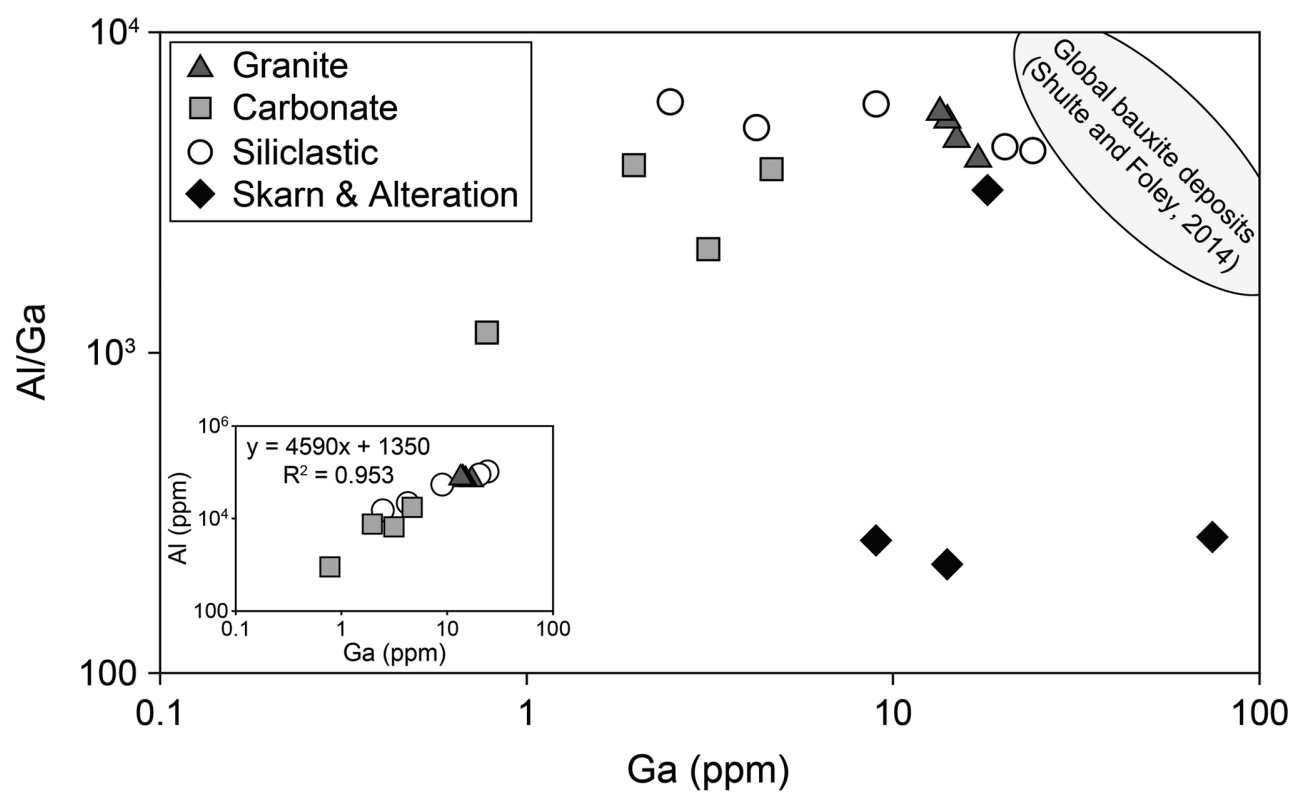

Figure 5. Plot of Al concentrations versus Al/Ga ratios in rocks from the Taebaeksan metallogenic region. Skarn and altered rocks in the Sangdong deposit show inconsistent trend of Al/Ga ratios compared to the unaltered lithologies, which might suggest an enrichment of Ga by a magmatic-hydrothermal fluid.

with a magmatic-hydrothermal activity such as a skarn type, while Ga is abundant in the lower temperature deposits such a MVT type (Cook et al., 2009; Frenzel et al., 2016b). This apparent temperature-dependent substituting affinities of In and Ga during the $\mathrm{Zn}$ mineralization have been applied for a sphalerite geothermometry (Frenzel et al., 2016a).
Mineral assemblages in the ores in general are temperature-dependent (Sullivan, 1957). Indium and Ga concentrations in the sphalerites show a relationship with their associating minerals (Fig. 6). Gallium-rich sphalerites commonly coexist with arsenopyrite and galena, whereas those sphalerites are depleted in In. Arsenopyrite and galena in the TBS

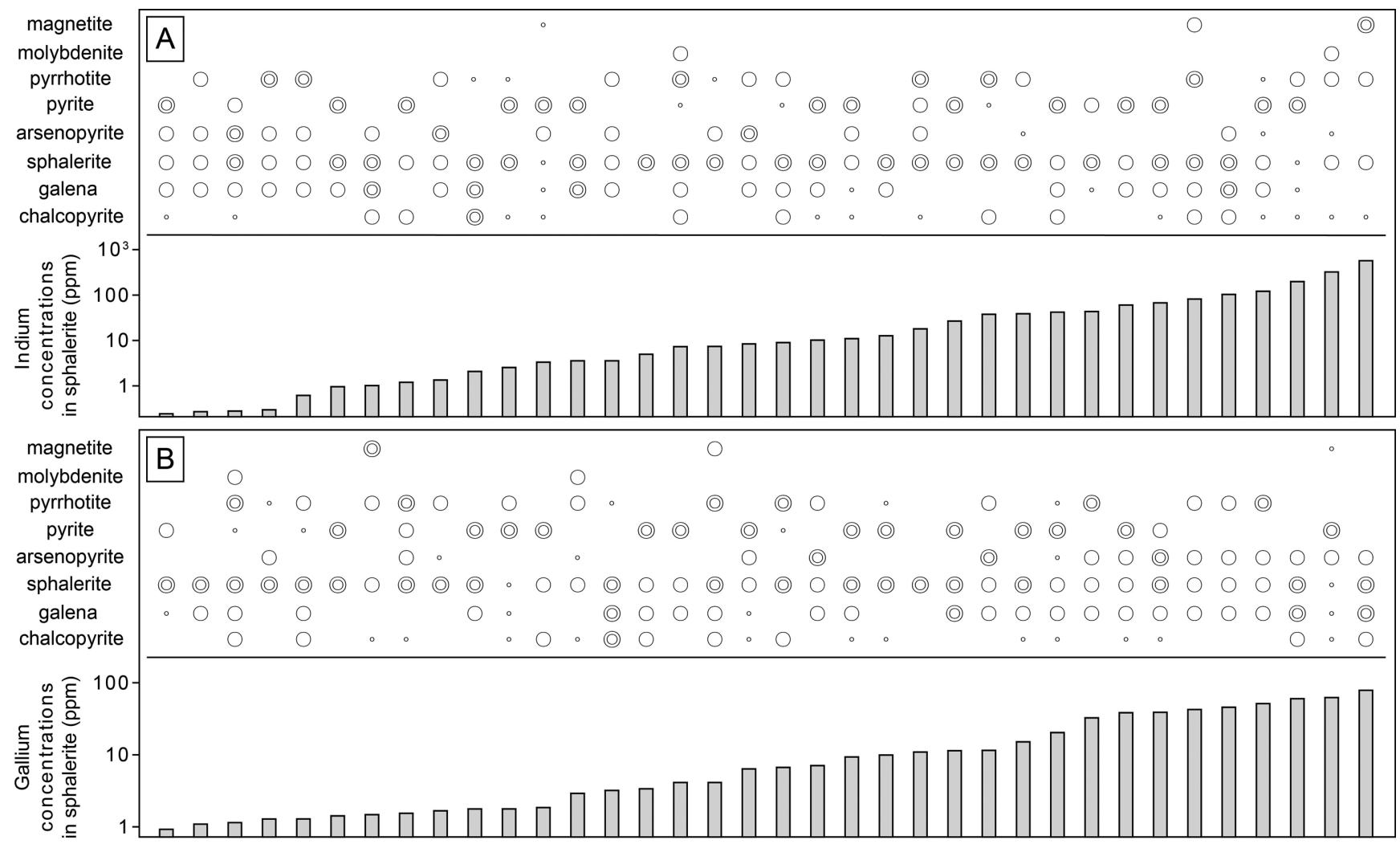

Figure 6. Mineral assemblages found in sphalerite-bearing ores from the Taebaeksan metallogenic region. The ores were arranged at increasing In and Ga concentrations in sphalerite. Data are from Lee et al. (2019). Dominant $=\bigcirc$; Common $=\bigcirc ;$ Rare $=0$. 


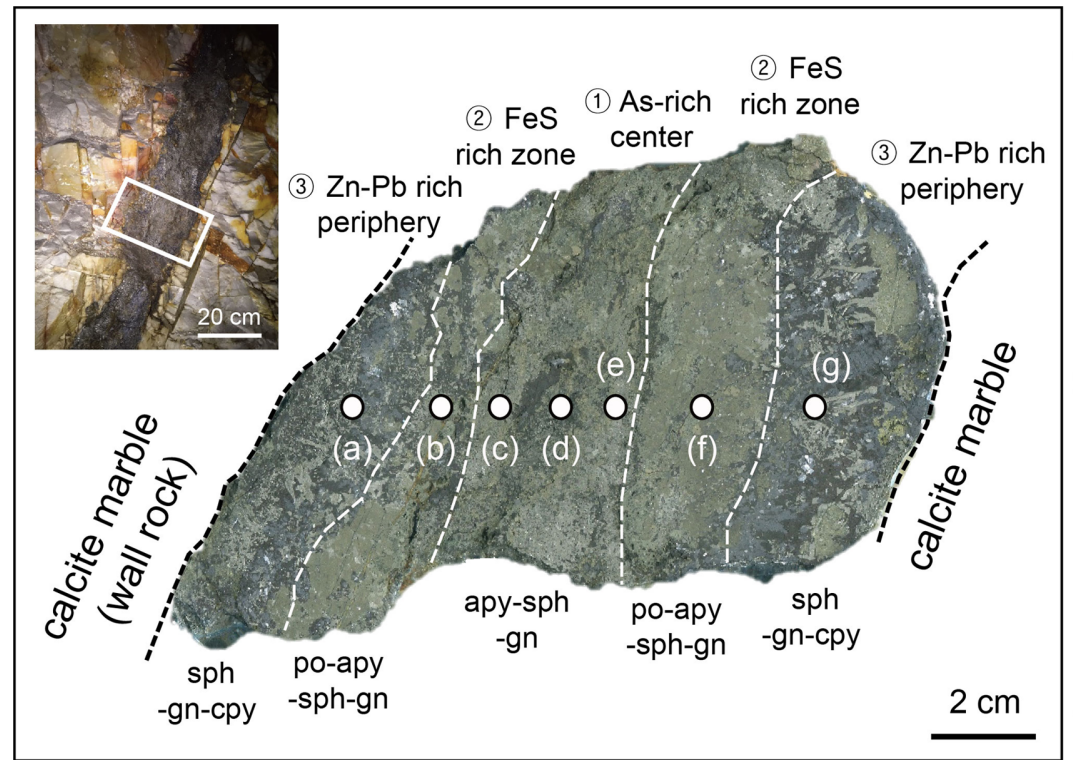

ppm in sphalerite (LA-ICP-MS)

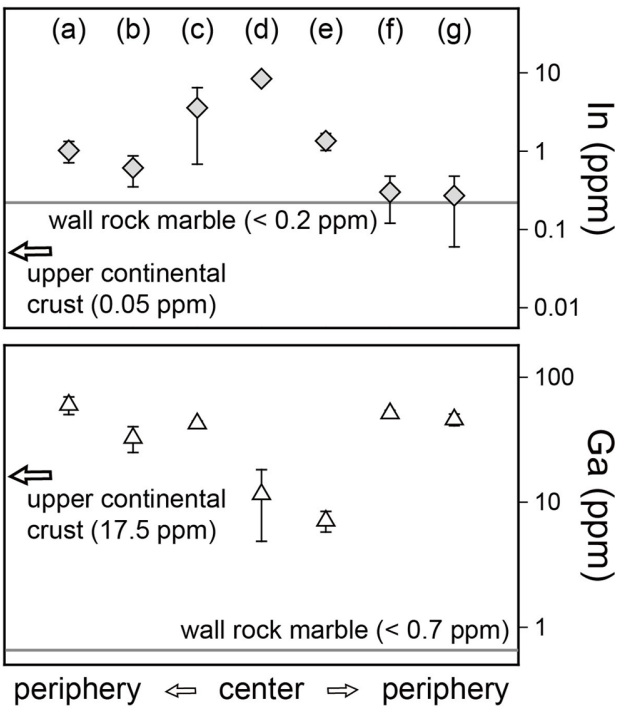

Figure 7. Lens-shaped Zn-Pb orebody replacing calcite marble in the Seongwoo calcite marble deposit and distributions of In and Ga concentrations in the ore. Sphalerites are sequentially associated with arsenopyrite, pyrrhotite, and chalcopyrite. Data are from Lee et al. (2019). Abbreviations: sph $=$ sphalerite, gn $=$ galena, apy $=$ arsenopyrite, po $=$ pyrrhotite, cpy $=$ chalcopyrite.

sphalerite-bearing ores are mainly associated in relatively later stage of paragenetic sequence which are possibly somewhat decreased hydrothermal temperature (Lee et al., 2019). This trend suggest that the mineral assemblages of sphalerite could be a possible indicator of In and $\mathrm{Ga}$ enrichments in the sulfide ores.

The lens-shaped ore prospect occurs in the Seongwoo calcite marble deposit show a distinctive spatio-temporal mineralization pattern from the ore center to the periphery near wall rock (Fig. 7). While the center is closely associated with arsenopyrite, the periphery is rich in sphalerite and galena. Even within a section of $15 \mathrm{~cm}$ intervals, In concentration in sphalerite of the center (about $8.7 \mathrm{ppm}$ ) is higher than that of the periphery (about $0.1 \mathrm{ppm}$ ), whereas Ga is higher in the periphery (about $66 \mathrm{ppm}$ ) showing a difference of $60 \mathrm{ppm}$ compared to the sphalerite in the center (about $6.2 \mathrm{ppm}$ ). Although a further study is necessary to identify mineralization temperatures of those sphalerites, it is clear that the enrichments of In and Ga are highly selective depending on the mineralization temperatures.

\section{Enrichment processes of In and Ga}

The incorporations of $\mathrm{In}(\mathrm{III})$ and $\mathrm{Ga}(\mathrm{III})$ in sphalerite are facilitated by a coupled substitution with some monovalent cations including $\mathrm{Cu}^{+}$and $\mathrm{Ag}^{+}$(e.g., $2 \mathrm{Zn}^{2+} \leftrightarrow \mathrm{Cu}^{+}+\mathrm{In}^{3+}$ ). In the TBS region, $\mathrm{Cu}$ was measured as the most abundant trace element in sphalerite and showed a positive correlation with In and Ga (Lee et al., 2019). Indium is reported to form chloride complexes such as $\mathrm{InCl}_{3}$ in relatively high temperature hydrothermal fluids up to $350^{\circ} \mathrm{C}$ (Seward et al., 2000), while Ga prefers to comprise a hydroxide complex such as $\mathrm{Ga}(\mathrm{OH})_{3}$ (Wood and Samson, 2006). Chemical reactions for the In- and Ga-bearing sphalerite precipitations from hydrothermal solution could be as follows:

$$
\begin{aligned}
& \mathrm{InCl}_{3(a q)}+\mathrm{CuCl}_{(a q)}+2 \mathrm{H}_{2} \mathrm{~S}_{(a q)} \leftrightarrow \mathrm{InCuS}_{2} \text { (substituted in sphalerite) } \\
& \quad+4 \mathrm{HCl}_{(\mathrm{aq})}
\end{aligned}
$$

and

$$
\begin{aligned}
& \mathrm{Ga}(\mathrm{OH})_{3(a q)}+\mathrm{CuCl}_{(a q)}+2 \mathrm{H}_{2} \mathrm{~S}_{(a q)} \leftrightarrow \mathrm{GaCuS}_{2} \text { (substituted in sphalerite) } \\
& +\mathrm{HCl}_{(\mathrm{aq})}+3 \mathrm{H}_{2} \mathrm{O}
\end{aligned}
$$

where the $\mathrm{In}-\mathrm{Cu}$ and the $\mathrm{Ga}-\mathrm{Cu}$ couples are incorporated into the sphalerite.

The reactions for the In- and Ga-bearing sphalerite precipitation can be promoted by a low acidity condition in the ore solution, which is advantageous in carbonate rock hosting $\mathrm{Zn}$ ores in the TBS region. Saline fluid is favorable to form an In-chloride complex for mobilization and enrichment of In. Audétat and Zhang (2019) reported that hypersaline brines in natural magmatic-hydrothermal fluids contain In ranging from 0.2 to $20 \mathrm{ppm}$, while $\mathrm{Ga}$ is low ranging up to $3 \mathrm{ppm}$. A formation of hydroxide $(\mathrm{OH})$, formed by a water dissociation, is highly temperature-dependent (Sweeton et al., 1974). The ionization constant of water $\left(\mathrm{p} K_{\mathrm{W}}\right)$ is generally low in the range of $200-300^{\circ} \mathrm{C}$ (lowest at $250^{\circ} \mathrm{C}$ ) and increases when temperature decreases (Bandura and Lvov, 2006), which indicates that Ga hydroxides might be more stable below $250^{\circ} \mathrm{C}$. Since the reactions 1 and 2 are redox-independent, contents of reducing materials such as a sedimentary organic C (e.g., TOC content; Table S2) in the hosting lithologies might not be a decisive factor for In and $\mathrm{Ga}$ enrichments.

\section{Conclusions}

In this study we investigated the geological distributions of In and $\mathrm{Ga}$ and discussed their enrichment processes in the TBS metallogenic region. While associating sedimentary and igneous lithologies in the TBS region have very low In contents, we found high In concentrations up to $630 \mathrm{ppm}$ in sphalerite. This suggests a significant In enrichment by regional magmatic-hydrothermal processes. Average concentration of In is about $100 \mathrm{ppm}$ in the Yeonhwa, Gagok, Uljin, and Shinyemi 
deposits where had been the major $\mathrm{Zn}$ producers in Korea. It suggests a potential of economic In orebodies in the region, which requires a further investigation of the $\mathrm{Zn}$ reserves and ore grade in the prospects for securing In resources. Enrichment of In in the TBS sphalerite might be closely associated with a magmatic-hydrothermal ore-forming process in the region, the high temperature and high salinity fluids might promote a formation of In-chloride complex.

Gallium concentrations in sphalerites (up to $66 \mathrm{ppm}$ ) in the TBS region are not significant, and its concentrations are comparable to the associating lithologies such as the granitoid intrusions (13-17 ppm) and unaltered sedimentary sequences (up to $24 \mathrm{ppm}$ ). While Ga can be enriched by a magmatic-hydrothermal fluid as well, the degree of $\mathrm{Ga}$ enrichment in sphalerite is not as high as In. Since a Ga enrichment might be related to a low temperature hydrothermal process due to its hydroxide complexation, we conclude that Ga might not be promising in the TBS region. Detailed future studies on the mineral assemblages of sphalerite-bearing ore and fluid inclusion microthermometry would further clarify the enrichment process and would provide useful tools for an exploration of In and Ga in the prospects.

\section{Acknowledgments}

This work is supported by the National Research Foundation of Korea (NRF) grant funded by the Korea government (MSIT) (No. 2019R1C1C1002588 and 2020R1A6A3A13075639) and by the Korea Institute for Geoscience and Mineral Resources (KIGAM) research projects "Geology and ore deposit survey and origin study for securing potential orebodies in the Taebaegsan metallogenic belt" (15-3211 and 16-3211) and "Verification of North Korean mineral resources exploration technologies and potential evaluation of North Korean mineral deposits" (19-8901 and 20-8901).

\section{References}

Audétat, A., and Zhang, D., 2019, Abundances of S, Ga, Ge, Cd, In, Tl and 32 other major to trace elements in high-temperature $\left(350-700^{\circ} \mathrm{C}\right)$ magmatic-hydrothermal fluids. Ore Geology Reviews, v. 109, pp. 630-642. doi: 10.1016/j.oregeorev.2019.05.017

Bandura, A.V., and Lvov, S.N., 2006, The ionization constant of water over wide ranges of temperature and density. Journal of Physical and Chemical Reference Data, v. 35, pp. 15-30. doi: 10.1063/1.1928231

Breiter, K., Gerdenova, N., Kanicky, V., and Vaculovic, T., 2013, Gallium and germanium geochemistry during magmatic fractionation and postmagmatic alteration in different types of granitoids: a case study from the Bohemian Massif (Czech Republic). Geologica Carpathica, v. 64, pp. 171-180. doi: 10.2478/geoca-2013-0018

Burton, J.D., Culkin, F., and Riley, J.P., 1959, The abundances of gallium and germanium in terrestrial materials. Geochimica et Cosmochimica Acta, v. 16, pp. 151-180. doi: 10.1016/0016-7037(59)90052-3

Burton, J.D., and Culkin, F., 1978, Gallium. In: Wedepohl, K.H. (Ed.), Handbook of geochemistry. Springer-Verlag, Berlin, p. 32-D-7.

Chang, H.W., Cheong, C.S., Park, H.I., and Chang, B. U., 1995, Lead isotopic study on the Dongnam Fe-Mo skarn deposit. Economic and Environmental Geology, v. 28, pp. 25-31.

Choi, B.K., Choi, S.-G., Seo, J., Yoo, I.-K., Kang, H.-S., and Koo, M.-H., 2010, Mineralogical and geochemical characteristics of the WolgokSeongok orebodies in the Gagok skarn deposit: Their genetic implica- tions. Economic and Environmental Geology, v. 43, pp. 477-490 (in Korean with English abstract).

Choi, S.-G., Choi, B.K., Ahn, Y.H., and Kim, T.H., 2009, Re-evaluation of genetic environments of zinc-lead deposits to predict hidden skarn orebody. Economic and Environmental Geology, v. 42, pp. 301-314 (in Korean with English abstract).

Choi, S.-G., Kang, J., and Lee, J.H., 2019, Predictive exploration of the Cretaceous major mineral deposits in Korea : Focusing on W-Mo mineralization. Economic and Environmental Geology, v. 52, pp. 323-336 (in Korean with English abstract). doi: 10.9719/EEG.2019.52.5.323

Chough, S.K., Kwon, S.-T., Ree, J.-H., and Choi, D.K., 2000, Tectonic and sedimentary evolution of the Korean peninsula: a review and new view. Earth-Science Reviews, v. 52, pp. 175-235. doi: 10.1016/s0012-8252(00) 00029-5

Cook, N.J., Ciobanu, C.L., Pring, A., Skinner, W., Shimizu, M., Danyushevsky, L., Saini-Eidukat, B., and Melcher, F., 2009, Trace and minor elements in sphalerite: A LA-ICPMS study. Geochimica et Cosmochimica Acta, v. 73, pp. 4761-4791. doi: 10.1016/j.gca.2009.05.045

Foley, N.K., Jaskula, B.W., Kimball, B.E., and Schulte, R.F., 2017, Chapter H. Gallium. In: Schulz, K.J., DeYoung, J.H., Jr., Seal, R.R., II, and Bradley, D.C. (Eds.), Critical mineral resources of the United StatesEconomic and environmental geology and prospects for future supply. U.S. Geological Survey, Professional Paper, 1802, pp. H1-H35. doi: $10.3133 / \mathrm{pp} 1802 \mathrm{H}$

Frenzel, M., Hirsch, T., and Gutzmer, J. 2016a, Gallium, germanium, indium, and other trace and minor elements in sphalerite as a function of deposit type - A meta-analysis. Ore Geology Reviews, v. 76, pp. 52-78. doi: 10.1016/j.oregeorev.2015.12.017

Frenzel M., Ketris, M.P., Seifert, T., and Gutzmer, J., 2016b, On the current and future availability of gallium. Resources Policy, v. 47, pp. 38-50. doi: 10.1016/j.resourpol.2015.11.005

Guillong, M., Meier, D.L., Allan, M.M., Heinrich, C.A., and Yardley, B.W.D., 2008, Appendix A6: SILLS: A MATLAB-based program for the reduction of laser ablation ICP-MS data of homogeneous materials and inclusions. Mineralogical Association of Canada Short Course, v. 40 , pp. $328-333$.

Heo, C.H., Lee, J.H., and Chi, S.J., 2008, Preliminary study on the revaluation of IT-industrial mineral commodities in the domestic metallic mines. Journal of the Korean Society of Mineral and Energy Resources Engineers, v. 45, pp. 734-742 (in Korean with English abstract).

Hong, Y.K., 1986, Geochemistry and K-Ar age of the Imog granite at the southwestern part of the Hambaeg basin, Korea. Journal of the Korean Institute of Mining Geology, v. 19, pp. 97-107.

Hwang, D.H., and Lee, J.Y., 1998, Ore genesis of the Wondong polymetallic mineral deposits in the Taebaegsan metallogenic province. Economic and Environmental Geology, v. 31, pp. 375-388 (in Korean with English abstract).

Im, H., and Shin, D., Mineral composition and genetic environmental of skarn and hydrothermal vein type ore bodies in Imog deposit. Proceedings Fall Joint Conference of the Geological Science, 2016, The Geological Society of Korea, Abstracts No.44, p. 226 (in Korean).

Im, H., Jeong, J.-Y., and Shin, D., 2020, Genetic environment of W skarn and $\mathrm{Pb}-\mathrm{Zn}$ vein mineralization associated with the Imog granite in the Taebaeksan Mineralized District, South Korea. Ore Geology Reviews, v. 126. doi: 10.1016/j.oregeorev.2020.103721

Ishihara, S., Murakami, H., and Marquez-Zavalia, M.F., 2011, Inferred indium resources of the Bolivian tin-polymetallic deposits. Resource Geology, v. 61, pp. 174-191. doi: 10.1111/j.1751-3928.2011.00157.x

Je, Y.-K., and Lee, E.-J., 1987, Exploration and development of the Taebaek orebody in the Yeonhwa $\mathrm{Pb}-\mathrm{Zn}$ mine. Journal of the Korean Institute of Mining Geology, v. 20, pp. 273-288 (in Korean).

Johan, Z., 1988, Indium and Germanium in the structure of sphalerite: an example of coupled substitution with copper. Mineralogy and Petrology, v. 39, pp. 211-229. doi: 10.1007/bf01163036

John, Y.W., 1963, Geology and origin of Sangdong tungsten mine, Repub- 
lic of Korea. Economic Geology, v. 58, pp. 1285-1300. doi: 10.2113/ gsecongeo.58.8.1285

Kim, H.S., 2019, Reassessment of the Pyeongan Supergroup: Metamorphism and deformation of the Songrim orogeny. Economic and Environmental Geology, v. 52, pp. 367-379 (in Korean with English abstract). doi: 10.9719/EEG.2019.52.5.367

Kim, K.-H., 1986, Petrology and petrochemistry of Sangdong granite. M.Sc. Thesis, Kyungpook National University, Daegu, Korea, 80 p (in Korean with English abstract).

Koh, Y.K., Choi, S.-G., So, C.S., Choi, S.H., and Uchida, E., 1992, Application of arsenopyrite geothermometry and sphalerite geobarometry to the Taebaek Pb-Zn(-Ag) deposit at Yeonhwa I mine, Republic of Korea. Mineralium Deposita, v. 27, pp. 58-65. doi: 10.1007/bf00196081

Lafargue, E., Marquis, F., and Pillot, D., 1998, Rock-Eval 6 applications in hydrocarbon exploration, production, and soil contamination studies. Oil \& Gas Science and Technology, v. 53, pp. 421-437. doi: 10.2516/ ogst: 1998036

Lee, H.K., Ko, S.J., and Imai, N., 1990, Genesis of the lead-zinc-silver and iron deposits of the Janggun mine, as related to their structural features: Structural control and wallrock alteration of ore formation. Journal of the Korean Institute of Mining Geology, v. 23, pp. 161-181 (in Korean with English abstract).

Lee, H.K., Lee, C.H., and Kim, S.J., 1996, Geochemistry of stable isotope and mineralization age of magnetite deposits from the Janggun mine, Korea. Economic and Environmental Geology, v. 29, pp. 411-419 (in Korean with English abstract).

Lee, H.K., Moon, H.S., and Oh, M.S., 2007, Economic mineral deposits in Korea. ACANET, Seoul, 762 p (in Korean).

Lee, J.-H., 2011, The results of drilling in Weondong mine area, the Taebaegsan Mineralized District, Republic of Korea. Economic and Environmental Geology, v. 44, pp. 313-320 (in Korean with English abstract). doi: 10.9719/EEG.2011.44.4.313

Lee, J.H., Yoo, B.C., Yang, Y.-S., Lee, T.H., and Seo, J.H., 2019, Sphalerite geochemistry of the $\mathrm{Zn}-\mathrm{Pb}$ orebodies in the Taebaeksan metallogenic province, Korea. Ore Geology Reviews, v. 107, pp. 1046-1067. doi: 10.1016/j.oregeorev.2019.03.030

Lokanc, M., Eggert, R., and Redlinger, M., 2015, The availability of Indium: The present, medium term, and long term. National Renewable Energy Laboratory (NREL), Colorado, $90 \mathrm{p}$.

Mielke, J.E., 1979, Composition of the Earth's crust and distribution of the elements. In: Siegel, F.R. (Ed.), Review of research on modern problems in geochemistry. United Nations Educational, Scientific and Cultural Organization, Paris, pp. 13-39.

Moon, K.J., 1989, REE patterns at the Sangdong tungsten skarn ore deposit, South Korea. Journal of the Geological Society of Korea, v. 25, pp. 205-215 (in Korean with English abstract).

Moon, K.J., 1991, Review of skarn ore deposits at the southern limb of the Baegunsan syncline in the Taebaeg basin of South Korea. Journal of the Geological Society of Korea, v. 27, pp. 271-292.

Murakami, H., and Ishihara, S., 2013, Trace elements of indium-bearing sphalerite from tin-polymetallic deposits in Bolivia, China and Japan: A femto-second LA-ICPMS study. Ore Geology Reviews, v. 53, pp. 223-243. doi: 10.1016/j.oregeorev.2013.01.010

Park, C., Song, Y., Chi, S.J., Kang, I.M., Yi, K., and Chung, D., 2013, U$\mathrm{Pb}$ (SHRIMP) and $\mathrm{K}$-Ar age dating of intrusive rocks and skarn minerals at the W-skarn in Weondong deposit. Journal of the Mineralogical Society of Korea, v. 26, pp. 161-174 (in Korean with English abstract). doi: $10.9727 /$ jmsk.2013.26.3.161

Park, H.I., Chang, H.W., and Jin, M.S., 1988, K-Ar ages of mineral deposits in the Taebaeg mountain district. Journal of the Korean Institute of Mining Geology, v. 21, pp. 57-67 (in Korean with English abstract).

Rongguo, C., Juan, G., Liwen, Y., Huy, D., and Liedtke, M., 2016, Supply and demand of lithium and gallium. Information Center of Ministry of Land and Resources, Beijing, $52 \mathrm{p}$.

Roskill, 2010, Indium: Global industry markets and outlook. Roskill Infor- mation Services Ltd, London, $142 \mathrm{p}$

Rudnick, R.L., and Gao, S., 2003, Composition of the continental crust. In: Holland, H.D., and Turekian, K.K. (Eds.), Treatise on Geochemistry. Elsevier-Pergamon, Oxford, pp. 1-64. doi: 10.1016/B0-08-043751-6/ 03016-4

Sato, K., Shibata, K., Uchiumi, S., and Shimazaki, H., 1981, Mineralization age of the Shinyemi $\mathrm{Zn}-\mathrm{Pb}-\mathrm{Mo}$ deposit in the Taebaegsan area, southern Korea. Mining Geology, v. 31, pp. 333-336. doi: 10.11456/ shigenchishitsu1951.31.333

Schulte, R.F., and Foley, N.K., 2014, Compilation of gallium resource data for bauxite deposits. U.S. Geological Survey, Open-File Report, 20131272, 14 p. doi: $10.3133 /$ ofr20131272

Schwarz-Schampera, U., and Herzig, P.M., 2002, Indium: Geology, mineralogy, and economics. Springer, Berlin, 257 p. doi: 10.1007/978-3662-05076-7

Schulz, K.J., DeYoung, J.H., Jr., Bradley, D.C., and Seal, R.R., II, 2017, Chapter A. Critical Mineral Resources of the United States-An Introduction. In: Schulz, K.J., DeYoung, J.H., Jr., Seal, R.R., II, and Bradley, D.C. (Eds.), Critical mineral resources of the United States-Economic and environmental geology and prospects for future supply. U.S. Geological Survey, Professional Paper, 1802, pp. A1-A14. doi: 10.3133/ pp1802A

Seo, J., Choi, S.-G., Koo, M., Oh, C.W., Ryu, I.-G., and Lee, G., 2020, A study of igneous rocks related to $\mathrm{Zn}$ - $\mathrm{Pb}$ mineralization in the Shinyemi and Gagok deposits of the Taebaeksan Basin, South Korea. Resource Geology, v. 70, pp. 215-232. doi: 10.1111/rge.12230

Seo, J.H., Yoo, B.C., Villa, I.M., Lee, J.H., Lee, T.-H., Kim, C.-S., and Moon, K.J., 2017, Magmatic-hydrothermal processes in Sangdong WMo deposit, Korea: Study of fluid inclusions and ${ }^{39} \mathrm{Ar}^{40} \mathrm{Ar}$ geochronology. Ore Geology Reviews, v. 91, pp. 316-334. doi: 10.1016/j.oregeorev.2017.09.019

Seo, J.H., Yoo, B.C., Yang, Y.-S., Lee, J.H., Jang, J., and Shin, D., 2020, Scheelite geochemistry of the Sangdong W-Mo deposit and W prospects in the southern Taebaeksan metallogenic region, Korea. Geosciences Journal. v. 24, pp. 701-721. doi: 10.1007/s12303-020-0005-z

Seward, T.M., Henderson, C.M.B., and Charnock, J.M., 2000, Indium(III) chloride complexing and solvation in hydrothermal solutions to $350^{\circ} \mathrm{C}$ : an EXAFS study. Chemical Geology, v. 167, pp. 117-127. doi: 10.1016/ S0009-2541(99)00204-1

Simons, B., Andersen, J.C.O., Shail, R.K., and Jenner, F.E., 2017, Fractionation of $\mathrm{Li}, \mathrm{Be}, \mathrm{Ga}, \mathrm{Nb}, \mathrm{Ta}, \mathrm{In}, \mathrm{Sn}, \mathrm{Sb}, \mathrm{W}$ and $\mathrm{Bi}$ in the peraluminous Early Permian Variscan granites of the Cornubian Batholith: precursor processes to magmatic-hydrothermal mineralisation. Lithos, v. 278281, pp. 491-512. doi: 10.1016/j.lithos.2017.02.007

So, C.S., Yun, S.T., and Koh, Y.K., 1993, Mineralogic, fluid inclusion, and stable isotope evidence for the genesis of carbonate-hosted $\mathrm{Pb}-\mathrm{Zn}(-\mathrm{Ag})$ orebodies of the Taebaek deposit, Republic of Korea. Economic Geology, v. 88 , pp. $855-872$. doi: 10.2113 /gsecongeo.88.4.855

Sullivan, C.J., 1957, Heat and temperature in ore deposition. Economic Geology, v. 52, pp. 5-24. doi: 10.2113/gsecongeo.52.1.5

Sweeton, F.H., Mesmer, R.E., and Baes, C.F., Jr., 1974, Acidity measurements at elevated temperatures. VII. Dissociation of water. Journal of Solution Chemistry, v. 3, pp. 191-214. doi: 10.1007/bf00645633

Taylor, S.R., and McLennan, S.M., 1995, The geochemical evolution of the continental crust. Reviews of Geophysics, v. 33, pp. 241-265. doi: 10.1029/95RG00262

USGS, 2019, Mineral commodity summaries 2019. U.S. Geological Survey, 200 p. doi: $10.3133 / 70202434$

Wood, S.A., and Samson, I.M., 2006, The aqueous geochemistry of gallium, germanium, indium and scandium. Ore Geology Reviews, v. 28, pp. 57-102. doi: 10.1016/j.oregeorev.2003.06.002

Yang, D.Y., 1991, Mineralogy, petrology and geochemistry of the magnesian skarn-type magnetite deposits at the Shinyemi mine, Republic of Korea. Ph.D. Thesis, Waseda University, Tokyo, $323 \mathrm{p}$.

Ye, L., Cook, N.J., Ciobanu, C.L., Liu, Y., Zhang, Q., Liu, T.G., Gao, W., 
Yang, Y.L., and Danyushevsky, L., 2011, Trace and minor elements in sphalerite from base metal deposits in South China: A LA-ICPMS study. Ore Geology Reviews, v. 39, pp. 188-217. doi: 10.1016/j.oregeorev.2011.03.001

Yoo, B.C., Ko, I.S., Ryoo, C.-R., Park, S.-W., Yoon, S.-J., Lee, B.H., Lee, J.-H., Jin, K.-M., Heo, C.-H., Sohn, S.I., Oh, I.H., and Lim, O., 2016, Geology and ore deposit survey, and origin study for securing potential orebody in the Taebaegsan metallogenic belt. Report of Korea Institute of Geoscience and Mineral Resources, GP2015-032-2016(2).

Yun, H.S., 1986, Petrochemical study on the Cretaceous granitic rocks in the southern area of Hambaeg basin. Journal of the Korean Institute of Mining Geology, v. 19, pp. 175-191 (in Korean with English Abstract). Yun, S., 1979a. Structural and compositional characteristics of skarn zinclead deposits in the Yeonhwa-Ulchin mining district, southeastern Tae-

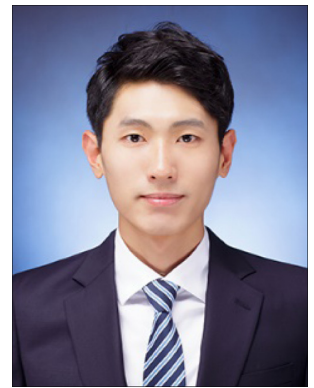

Jun Hee Lee is a PhD student at Department of Energy Resources Engineering, Inha University, Korea. His $\mathrm{PhD}$ research is focused on geochemistry and exploration of magmatichydrothermal $\mathrm{Zn}-\mathrm{Pb}$ deposits in the Korean Peninsula. baegsan region, Korea Part I: The Yeonhwa I mine. Journal of the Korean Institute of Mining Geology, v. 12, pp. 51-73.

Yun, S., 1979b. Structural and compositional characteristics of skarn zinclead deposits in the Yeonhwa-Ulchin mining district, southeastern Taebaegsan region, Korea Part II: The Yeonhwa II mine. Journal of the Korean Institute of Mining Geology, v. 12, pp. 147-176.

Yun, S., and Einaudi, M.T., 1982, Zinc-lead skarns of the Yeonhwa-Ulchin district, South Korea. Economic Geology, v. 77, pp. 1013-1032. doi: 10.2113/gsecongeo.77.4.1013

Yun, S., and Silberman, M.L., 1979, K-Ar geochronology of igneous rocks in the Yeonhwa-Ulchin zinc-lead district and southern margin of the Taebaegsan basin, Korea. Journal of the Geological Society of Korea, v. 15 , pp. 89-100.



Jung Hun Seo is an associate professor of Economic Geology and Geochemistry at Department of Energy Resources Engineering, Inha University, Korea. He received his $\mathrm{PhD}$ degree from ETH Zürich, Switzerland. His current research interests include geochemistry of W-Mo deposits, seafloor magmatic-hydrothermal systems, and stable isotope geochemistry of rocks from Antarctic MOR. He has served as an editorial board member for Geosciences Journal and for Economic and Environmental Geology. 
Table S1. Summarized details of rock samples collected from the Taebaeksan metallogenic province

\begin{tabular}{|c|c|c|c|}
\hline Sample number & $\begin{array}{l}\text { Name and stratigraphy of the } \\
\text { sampled rocks }\end{array}$ & $\begin{array}{l}\text { Sampling location } \\
\text { (GPS coordinates) }\end{array}$ & Description \\
\hline SD_granite01 & Sangdong granite (drill core) & $37^{\circ} 9^{\prime} 7^{\prime \prime} \mathrm{N} / 128^{\circ} 50^{\prime} 3 " \mathrm{E}$ & $\begin{array}{l}\text { K-feldspar-rich muscovite granite recovered from drillcore in } \\
\text { the Sangdong W-Mo deposit }\end{array}$ \\
\hline SD_S01 & $\begin{array}{l}\text { M1 layer in Myobong Formation } \\
\text { (underground) }\end{array}$ & $37^{\circ} 9^{\prime} 7^{\prime \prime} \mathrm{N} / 128^{\circ} 50^{\prime} 3 " \mathrm{E}$ & $\begin{array}{l}\text { garnet-wollastonite-rich skarn in M1 layer in the Sangdong } \\
\text { W-Mo deposit }\end{array}$ \\
\hline SD_S02 & $\begin{array}{l}\text { M1 layer in Myobong Formation } \\
\text { (underground) }\end{array}$ & $37^{\circ} 9^{\prime} 7^{\prime \prime} \mathrm{N} / 128^{\circ} 50^{\prime} 3 " \mathrm{E}$ & $\begin{array}{l}\text { clinopyroxene-rich skarn in M1 carbonate layer in the } \\
\text { Sangdong W-Mo deposit }\end{array}$ \\
\hline SD19 & $\begin{array}{l}\text { M1 layer in Myobong Formation } \\
\text { (underground) }\end{array}$ & $37^{\circ} 9^{\prime} 7^{\prime \prime} \mathrm{N} / 128^{\circ} 50^{\prime} 3 " \mathrm{E}$ & $\begin{array}{l}\text { amphibole-magnetite rich alteration in M1 carbonate layer in } \\
\text { the Sangdong W-Mo deposit }\end{array}$ \\
\hline SD16 & $\begin{array}{l}\text { M1 layer in Myobong Formation } \\
\text { (underground) }\end{array}$ & $37^{\circ} 9^{\prime} 7^{\prime \prime} \mathrm{N} / 128^{\circ} 50^{\prime} 3^{\prime \prime} \mathrm{E}$ & $\begin{array}{l}\text { mica-rich alteration in M1 carbonate layer in the Sangdong } \\
\text { W-Mo deposit }\end{array}$ \\
\hline SD_PC01 & $\begin{array}{l}\text { upper part of Pungchon Formation } \\
\text { (drill core) }\end{array}$ & $37^{\circ} 8^{\prime} 53^{\prime \prime} \mathrm{N} / 128^{\circ} 49^{\prime} 42^{\prime \prime} \mathrm{E}$ & $\begin{array}{l}\text { megacryst of calcite }(1-2 \mathrm{~cm}) \text { in marble in the Sangdong } \\
\text { high-Ca marble deposit }\end{array}$ \\
\hline JS_PC01 & $\begin{array}{l}\text { lower part of Pungchon Formation } \\
\text { (outcrop) }\end{array}$ & $37^{\circ} 8^{\prime} 50^{\prime \prime} \mathrm{N} / 128^{\circ} 49^{\prime} 58^{\prime \prime} \mathrm{E}$ & partly oolitic and partly recrystallized dark gray limestone \\
\hline JS_MB01 & Myobong Formation (outcrop) & $37^{\circ} 9^{\prime} 28^{\prime \prime} \mathrm{N} / 128^{\circ} 48^{\prime} 6^{\prime \prime} \mathrm{E}$ & laminated dark gray and fine-grained slate \\
\hline JS_MB02 & Myobong Formation (outcrop) & $37^{\circ} 8^{\prime} 44^{\prime \prime} \mathrm{N} / 128^{\circ} 50^{\prime} 35^{\prime \prime} \mathrm{E}$ & massive slate to mudstone with quartz and muscovite grain \\
\hline JS_MB03 & $\begin{array}{l}\text { M1 layer in Myobong Formation } \\
\text { (outcrop) }\end{array}$ & $37^{\circ} 9^{\prime} 30^{\prime \prime} \mathrm{N} / 128^{\circ} 48^{\prime} 6^{\prime \prime} \mathrm{E}$ & $\begin{array}{l}\text { partly recrystallized limestone with quartz grain, wavy thin } \\
\text { quartz veins }(\sim 1 \mathrm{~mm}) \text { crosscut }\end{array}$ \\
\hline JS_JSQ01 & Jangsan Formation (outcrop) & $37^{\circ} 9^{\prime} 12^{\prime \prime} \mathrm{N} / 128^{\circ} 48^{\prime} 22^{\prime \prime} \mathrm{E}$ & laminated quartzite with disseminated pyrite \\
\hline JS_JSQ02 & Jangsan Formation (outcrop) & $37^{\circ} 8^{\prime} 43^{\prime \prime} \mathrm{N} / 128^{\circ} 50^{\prime} 30^{\prime \prime} \mathrm{E}$ & quartzite with crossbedding with sericite \\
\hline SBW_BS01 & $\begin{array}{l}\text { Precambrian metamorphic basement } \\
\text { (outcrop) }\end{array}$ & $37^{\circ} 7^{\prime} 54^{\prime \prime} \mathrm{N} / 128^{\circ} 48^{\prime} 31^{\prime \prime} \mathrm{E}$ & $\begin{array}{l}\text { meta-sandstone to meta-siltstone with muscovite in the } \\
\text { Sunbawi area }\end{array}$ \\
\hline IM_granite 01 & Imog granite (outcrop) & $37^{\circ} 9^{\prime} 40^{\prime \prime} \mathrm{N} / 128^{\circ} 40^{\prime} 9^{\prime \prime} \mathrm{E}$ & K-feldspar rich seriate biotite granite \\
\hline IM_granite 02 & Imog granite (outcrop) & $37^{\circ} 9^{\prime} 43^{\prime \prime} \mathrm{N} / 128^{\circ} 40^{\prime} 51^{\prime \prime E}$ & K-feldspar rich seriate biotite granite \\
\hline SYM_grainte01 & Shinyemi granite (drill core) & $37^{\circ} 11^{\prime} 34^{\prime \prime} \mathrm{N} / 128^{\circ} 40^{\prime} 7^{\prime \prime} \mathrm{E}$ & $\begin{array}{l}\text { K-feldspar rich fine-grained biotite granite recovered from } \\
\text { drillcore in the Shinyemi Fe- } \mathrm{Zn}-\mathrm{Pb} \text { deposit }\end{array}$ \\
\hline JS_MG01 & Makgol Formation (outcrop) & $37^{\circ} 11^{\prime} 39^{\prime \prime} \mathrm{N} / 128^{\circ} 40^{\prime} 35^{\prime \prime} \mathrm{E}$ & light gray dolomitic limestone \\
\hline JS_DMG01 & Dumugol Formation (outcrop) & $37^{\circ} 10^{\prime} 13^{\prime \prime} \mathrm{N} / 128^{\circ} 39^{\prime} 12^{\prime \prime} \mathrm{E}$ & lenticular laminated gray limestone \\
\hline JS_HJ01 & Hwajeol Formation (outcrop) & $37^{\circ} 10^{\prime} 11^{\prime \prime} \mathrm{N} / 128^{\circ} 39^{\prime} 36^{\prime \prime} \mathrm{E}$ & massive and fine-grained calcite crystallized limestone \\
\hline SJ_PC01 & $\begin{array}{l}\text { upper part of Pungchon Formation } \\
\text { (drill core) }\end{array}$ & $37^{\circ} 10^{\prime} 24^{\prime \prime} \mathrm{N} / 128^{\circ} 40^{\prime} 42^{\prime \prime} \mathrm{E}$ & $\begin{array}{l}\text { sugary grained calcite }(\sim 0.2 \mathrm{~cm}) \text { marble in the Seojin high-Ca } \\
\text { marble deposit }\end{array}$ \\
\hline
\end{tabular}


Table S2. Complete dataset of chemical compositions of rock samples from the Taebaeksan metallogenic province

\begin{tabular}{|c|c|c|c|c|c|c|c|c|c|c|c|c|c|c|}
\hline \multirow{2}{*}{ Sample number } & \multicolumn{2}{|c|}{ "Rock-Eval (wt\%) } & \multicolumn{12}{|c|}{ "XRF (wt\%) } \\
\hline & TOC & mineral $\mathrm{C}$ & $\mathrm{SiO}_{2}$ & $\mathrm{TiO}_{2}$ & $\mathrm{Al}_{2} \mathrm{O}_{3}$ & $\mathrm{Fe}_{2} \mathrm{O}_{3}$ & $\mathrm{MnO}$ & $\mathrm{MgO}$ & $\mathrm{CaO}$ & $\mathrm{Na}_{2} \mathrm{O}$ & $\mathrm{K}_{2} \mathrm{O}$ & $\mathrm{P}_{2} \mathrm{O}_{5}$ & LOI & Sum \\
\hline SD_granite01 & NA & NA & 71.6 & 0.2 & 13.0 & 1.6 & 0.1 & 0.3 & 1.2 & 2.8 & 5.0 & 0.0 & 3.4 & 99.1 \\
\hline SD_S01 & 0.07 & 0.60 & 40.6 & 0.0 & 0.6 & 13.6 & 0.4 & 0.8 & 34.9 & 0.1 & 1.2 & 0.1 & 7.2 & 99.5 \\
\hline SD_S02 & 0.02 & 0.03 & 44.7 & 0.0 & 0.4 & 23.2 & 1.4 & 0.8 & 26.2 & 0.1 & 0.0 & 0.0 & 0.0 & 97.0 \\
\hline SD19 & 0.02 & 0.04 & 38.5 & 0.1 & 3.7 & 44.0 & 0.5 & 1.3 & 6.9 & 0.4 & 0.5 & 0.1 & 0.8 & 96.8 \\
\hline SD16 & 0.02 & 0.06 & 65.1 & 0.9 & 11.0 & 8.2 & 0.2 & 2.7 & 4.9 & 0.6 & 2.0 & 0.3 & 3.1 & 98.9 \\
\hline SD_PC01 & 0.04 & 9.66 & 3.4 & 0.0 & 0.0 & 0.0 & 0.0 & 0.2 & 52.1 & 0.0 & 0.1 & 0.0 & 43.3 & 99.2 \\
\hline JS_PC01 & 0.13 & 9.92 & 4.5 & 0.0 & 0.4 & 0.4 & 0.1 & 3.0 & 48.4 & 0.1 & 0.1 & 0.1 & 42.8 & 99.8 \\
\hline JS_MB01 & 0.02 & 0.01 & 57.5 & 0.9 & 19.4 & 7.7 & 0.1 & 2.6 & 0.2 & 0.5 & 5.9 & 0.1 & 3.9 & 98.7 \\
\hline JS_MB02 & 0.06 & 0.04 & 50.7 & 3.1 & 16.7 & 12.1 & 0.2 & 3.1 & 2.5 & 0.4 & 5.7 & 0.2 & 3.9 & 98.7 \\
\hline JS_MB03 & 0.15 & 9.56 & 14.8 & 0.1 & 1.4 & 1.6 & 0.4 & 0.8 & 42.7 & 0.1 & 0.4 & 0.2 & 37.2 & 99.8 \\
\hline JS_JSQ01 & 0.02 & 0.01 & 90.8 & 0.1 & 2.8 & 2.7 & 0.0 & 0.1 & 0.3 & 0.0 & 0.8 & 0.1 & 2.2 & 99.8 \\
\hline JS_JSQ02 & 0.02 & 0.01 & 91.8 & 0.2 & 4.0 & 0.5 & 0.0 & 0.1 & 0.2 & 0.1 & 1.1 & 0.0 & 2.0 & 100.0 \\
\hline SBW_BS01 & 0.06 & 0.43 & 75.4 & 0.2 & 10.1 & 2.5 & 0.1 & 0.7 & 2.0 & 2.8 & 1.3 & 0.1 & 4.9 & 100.1 \\
\hline IM_granite01 & NA & NA & 70.1 & 0.4 & 14.2 & 3.4 & 0.1 & 1.3 & 2.3 & 2.8 & 3.6 & 0.1 & 2.3 & 100.6 \\
\hline IM_granite02 & NA & NA & 66.9 & 0.4 & 14.3 & 3.2 & 0.1 & 1.3 & 2.7 & 2.8 & 4.3 & 0.1 & 2.0 & 98.1 \\
\hline SYM_granite 01 & NA & NA & 75.4 & 0.1 & 13.0 & 1.3 & 0.1 & 0.2 & 0.6 & 3.2 & 5.0 & 0.0 & 1.9 & 100.8 \\
\hline JS_MG01 & 0.10 & 12.24 & 2.8 & 0.0 & 0.2 & 0.4 & 0.0 & 21.5 & 28.6 & 0.1 & 0.1 & 0.0 & 46.7 & 100.3 \\
\hline JS_DMG01 & 0.13 & 9.92 & 7.7 & 0.1 & 1.2 & 0.4 & 0.0 & 1.8 & 46.2 & 0.0 & 0.8 & 0.0 & 40.8 & 99.1 \\
\hline JS_HJ01 & 0.08 & 8.80 & 14.9 & 0.1 & 3.3 & 1.4 & 0.1 & 1.5 & 42.0 & 0.1 & 1.5 & 0.0 & 34.1 & 99.0 \\
\hline SJ_PC01 & 0.02 & 10.11 & 2.7 & 0.0 & 0.0 & 0.0 & 0.0 & 0.4 & 52.6 & 0.0 & 0.0 & 0.0 & 43.5 & 99.3 \\
\hline
\end{tabular}

$\mathrm{NA}=$ not analyzed 


\section{Table S2. Continued}

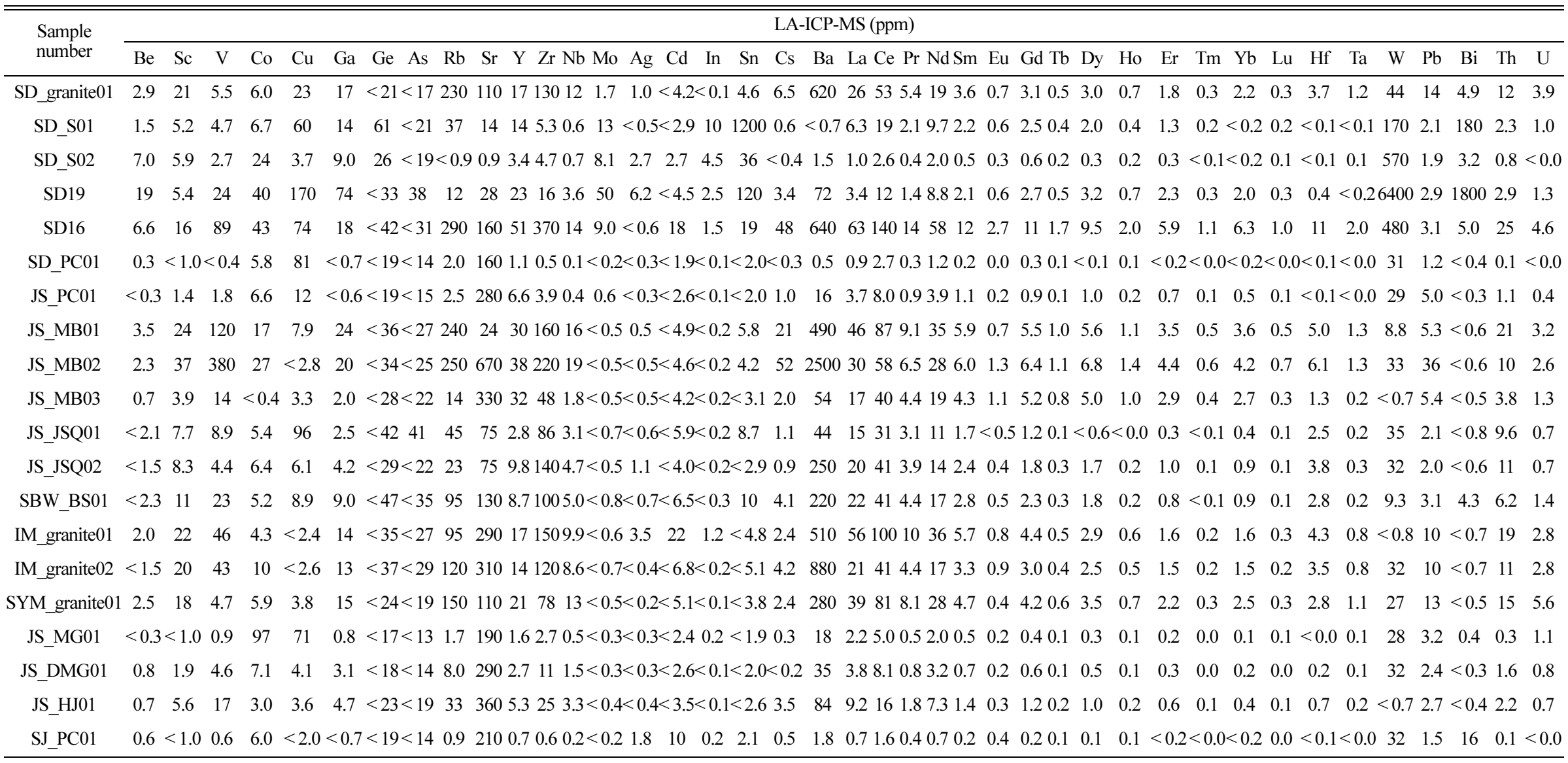

